\title{
LEVEL II SCOUR ANALYSIS FOR BRIDGE 42 (BRNETH00810042) on TOWN HIGHWAY 81, crossing the STEVENS RIVER, BARNET, VERMONT
}

Open-File Report 98-289

Prepared in cooperation with

VERMONT AGENCY OF TRANSPORTATION

and

FEDERAL HIGHWAY ADMINISTRATION

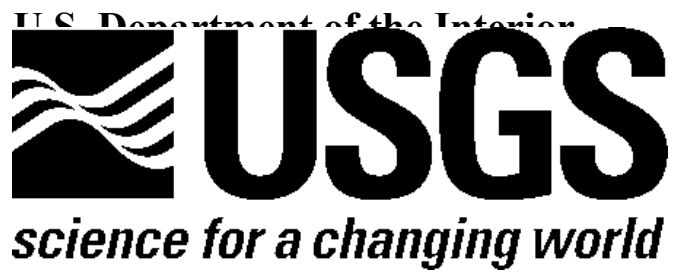




\section{LEVEL II SCOUR ANALYSIS FOR BRIDGE 42 (BRNETH00810042) on TOWN HIGHWAY 81, crossing the STEVENS RIVER, BARNET, VERMONT}

By MICHELLE M. SERRA

U.S. Geological Survey Open-File Report 98-289

Prepared in cooperation with

VERMONT AGENCY OF TRANSPORTATION and

FEDERAL HIGHWAY ADMINISTRATION 


\title{
U.S. DEPARTMENT OF THE INTERIOR BRUCE BABBITT, Secretary
}

\author{
U.S. GEOLOGICAL SURVEY
}

Thomas J. Casadevall, Acting Director

For additional information write to:

District Chief

U.S. Geological Survey 361 Commerce Way

Pembroke, NH 03275-3718
Copies of this report may be purchased from:

U.S. Geological Survey

Branch of Information Services

Open-File Reports Unit

Box 25286

Denver, CO 80225-0286 


\section{CONTENTS}

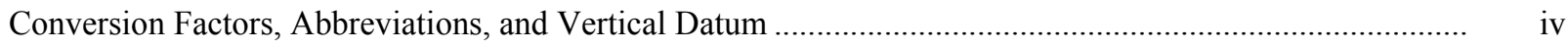

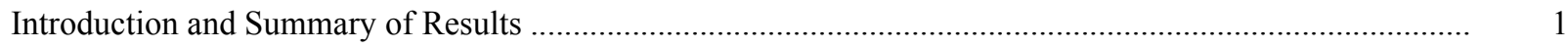

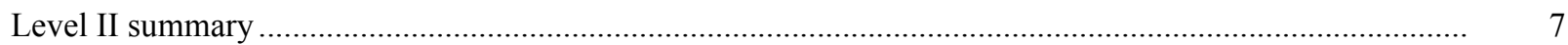

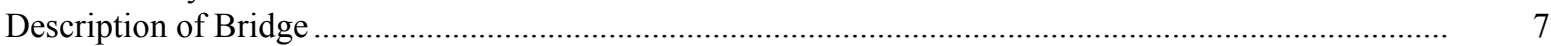

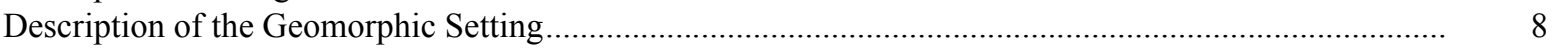

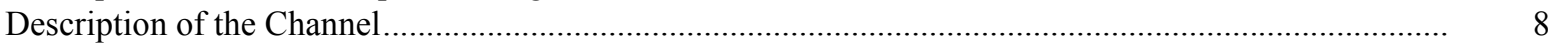

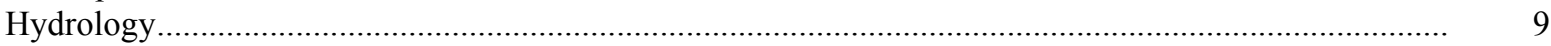

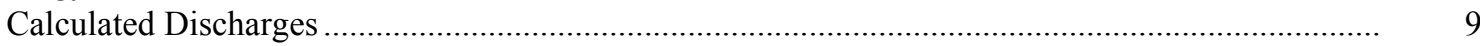

Description of the Water-Surface Profile Model (WSPRO) Analysis .................................................... 10

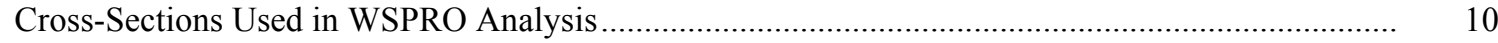

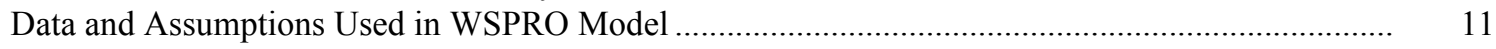

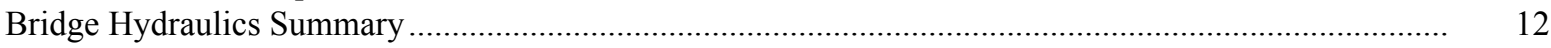

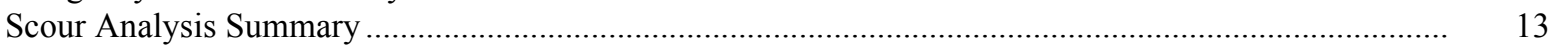

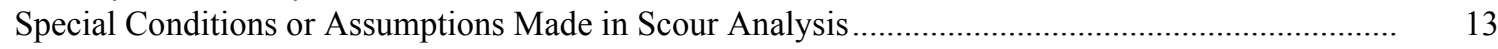

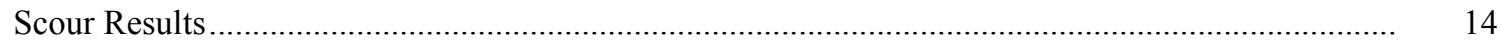

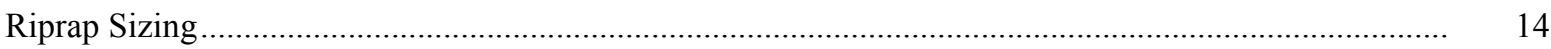

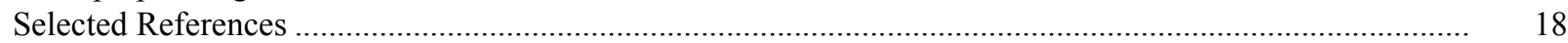

Appendices:

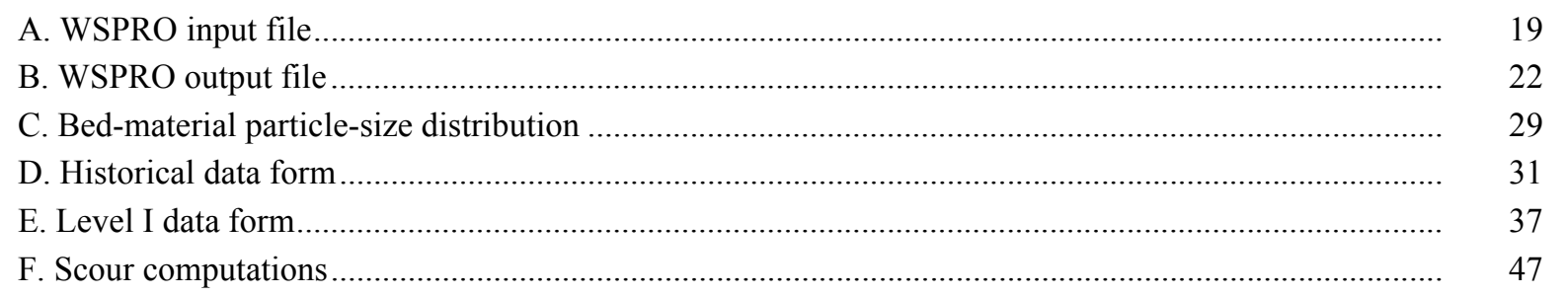

\section{FIGURES}

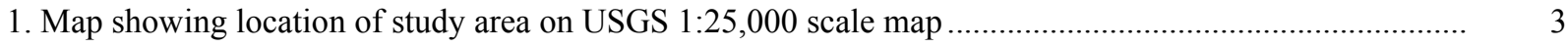

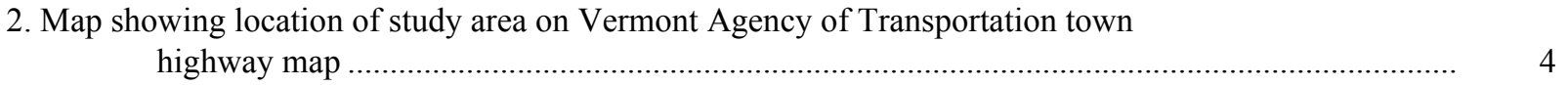

3. Structure BRNETH00810042 viewed from upstream (August 23, 1995) ......................................... 5

4. Downstream channel viewed from structure BRNETH00810042 (August 23, 1995)........................... 5

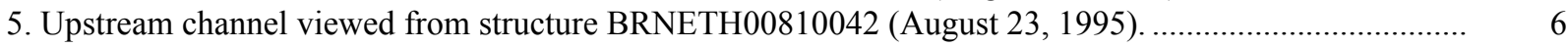

6. Structure BRNETH00810042 viewed from downstream (August 23, 1995)............................................ 6

7. Water-surface profiles for the 100- and 500-year discharges at structure

BRNETH00810042 on Town Highway 81, crossing the Stevens River, Barnet, Vermont. (n)

8. Scour elevations for the 100- and 500-year discharges at structure

BRNETH00810042 on Town Highway 81, crossing the Stevens River,

Barnet, Vermont.

\section{TABLES}

1. Remaining footing/pile depth at abutments for the 100-year discharge at structure BRNETH00810042 on Town Highway 81, crossing the Stevens River,

Barnet, Vermont.

2. Remaining footing/pile depth at abutments for the 500-year discharge at structure BRNETH00810042 on Town Highway 81, crossing the Stevens River, Barnet, Vermont. 


\begin{tabular}{|c|c|c|}
\hline Multiply & By & To obtain \\
\hline \multicolumn{3}{|c|}{ Length } \\
\hline inch (in.) & 25.4 & millimeter (mm) \\
\hline foot $(\mathrm{ft})$ & 0.3048 & meter $(\mathrm{m})$ \\
\hline mile (mi) & 1.609 & kilometer (km) \\
\hline \multicolumn{3}{|c|}{ Slope } \\
\hline foot per mile ( $\mathrm{ft} / \mathrm{mi})$ & 0.1894 & meter per kilometer $(\mathrm{m} / \mathrm{km})$ \\
\hline \multicolumn{3}{|c|}{ Area } \\
\hline square mile $\left(\mathrm{mi}^{2}\right)$ & 2.590 & square kilometer $\left(\mathrm{km}^{2}\right)$ \\
\hline \multicolumn{3}{|c|}{ Volume } \\
\hline cubic foot $\left(\mathrm{ft}^{3}\right)$ & $\begin{array}{l}0.02832 \\
\text { Velocity and Flow }\end{array}$ & cubic meter $\left(\mathrm{m}^{3}\right)$ \\
\hline foot per second (ft/s) & 0.3048 & meter per second $(\mathrm{m} / \mathrm{s})$ \\
\hline cubic foot per second $\left(\mathrm{ft}^{3} / \mathrm{s}\right)$ & 0.02832 & cubic meter per second $\left(\mathrm{m}^{3} / \mathrm{s}\right)$ \\
\hline $\begin{array}{l}\text { cubic foot per second per } \\
\text { square mile } \\
{\left[\left(\mathrm{ft}^{3} / \mathrm{s}\right) / \mathrm{mi}^{2}\right]}\end{array}$ & 0.01093 & $\begin{array}{l}\text { cubic meter per } \\
\text { second per square } \\
\text { kilometer }\left[\left(\mathrm{m}^{3} / \mathrm{s}\right) / \mathrm{km}^{2}\right]\end{array}$ \\
\hline
\end{tabular}

\section{OTHER ABBREVIATIONS}

\begin{tabular}{|c|c|c|c|}
\hline $\mathrm{BF}$ & bank full & LWW & left wingwall \\
\hline $\mathrm{cfs}$ & cubic feet per second & Max & maximum \\
\hline $\mathrm{D}_{50}$ & median diameter of bed material & $\mathrm{MC}$ & main channel \\
\hline DS & downstream & RAB & right abutment \\
\hline elev. & elevation & RABUT & face of right abutment \\
\hline $\mathrm{f} / \mathrm{p}$ & flood plain & $\mathrm{RB}$ & right bank \\
\hline $\mathrm{ft}^{2}$ & square feet & ROB & right overbank \\
\hline $\mathrm{ft} / \mathrm{ft}$ & feet per foot & RWW & right wingwall \\
\hline FEMA & Federal Emergency Management Agency & $\mathrm{TH}$ & town highway \\
\hline FHWA & Federal Highway Administration & UB & under bridge \\
\hline JCT & junction & US & upstream \\
\hline LAB & left abutment & USGS & United States Geological Survey \\
\hline LABUT & face of left abutment & VTAOT & Vermont Agency of Transportation \\
\hline LB & left bank & WSPRO & water-surface profile model \\
\hline LOB & left overbank & $\mathrm{yr}$ & year \\
\hline
\end{tabular}

In this report, the words "right" and "left" refer to directions that would be reported by an observer facing downstream. Sea level: In this report, "sea level" refers to the National Geodetic Vertical Datum of 1929-- a geodetic datum derived from a general adjustment of the first-order level nets of the United States and Canada, formerly called Sea Level Datum of 1929.

In the appendices, the above abbreviations may be combined. For example, USLB would represent upstream left bank. 


\title{
LEVEL II SCOUR ANALYSIS FOR BRIDGE 42 (BRNETH00810042) ON TOWN HIGHWAY 81, CROSSING THE STEVENS RIVER, BARNET, VERMONT
}

\author{
By Michelle M. Serra
}

\section{INTRODUCTION AND SUMMARY OF RESULTS}

This report provides the results of a detailed Level II analysis of scour potential at structure BRNETH00810042 on Town Highway 81 crossing the Stevens River, Barnet, Vermont (figures 1-8). A Level II study is a basic engineering analysis of the site, including a quantitative analysis of stream stability and scour (FHWA, 1993). Results of a Level I scour investigation also are included in appendix $\mathrm{E}$ of this report. A Level I investigation provides a qualitative geomorphic characterization of the study site. Information on the bridge, gleaned from Vermont Agency of Transportation (VTAOT) files, was compiled prior to conducting Level I and Level II analyses and is found in appendix D.

The site is in the New England Upland section of the New England physiographic province in northeastern Vermont. The $20.7-\mathrm{mi}^{2}$ drainage area is in a predominantly forested basin. In the vicinity of the study site, the surface cover is pasture on the left bank of the channel, upstream and downstream of the bridge. The right bank is predominantly shrub and brushland.

In the study area, Stevens River has an incised, straight channel with a slope of approximately $0.01 \mathrm{ft} / \mathrm{ft}$, an average channel top width of $36 \mathrm{ft}$ and an average bank height of $2 \mathrm{ft}$. The channel bed material ranges from sand to boulders with a median grain size $\left(\mathrm{D}_{50}\right)$ of $55.0 \mathrm{~mm}(0.181 \mathrm{ft})$. The geomorphic assessment at the time of the Level I and Level II site visit on August 23, 1995, indicated that the reach was stable.

The Town Highway 81 crossing of the Stevens River is a 29 -ft-long, one-lane bridge consisting of one 25-foot steel-beam span (Vermont Agency of Transportation, written communication, March 23, 1995). The opening length of the structure parallel to the bridge face is $22.3 \mathrm{ft}$. The bridge is supported by vertical, concrete abutments with wingwalls. The channel is skewed approximately 15 degrees to the opening while the opening-skew-toroadway is 15 degrees. 
A scour hole $1.5 \mathrm{ft}$ deeper than the mean thalweg depth was observed in the center of the channel immediately downstream of the bridge during the Level I assessment. Scour protection measures at this site consisted of type-1 stone fill (less than 12 inches diameter) at the downstream right wingwall, type- 2 stone fill (less than 36 inches diameter) at the upstream left and right wingwalls, the downstream left wingwall, and the right abutment, and type-3 stone fill (less than 48 inches diameter) at the left abutment. Additional details describing conditions at the site are included in the Level II Summary and appendices D and E.

Scour depths and recommended rock rip-rap sizes were computed using the general guidelines described in Hydraulic Engineering Circular 18 (Richardson and Davis, 1995) for the 100- and 500-year discharges. In addition, the incipient roadway-overtopping discharge was determined and analyzed as another potential worst-case scour scenario. Total scour at a highway crossing is comprised of three components: 1) long-term streambed degradation; 2) contraction scour (due to accelerated flow caused by a reduction in flow area at a bridge) and; 3 ) local scour (caused by accelerated flow around piers and abutments). Total scour is the sum of the three components. Equations are available to compute depths for contraction and local scour and a summary of the results of these computations follows.

Contraction scour for all modelled flows ranged from 0.0 to $3.7 \mathrm{ft}$. The worst-case contraction scour occurred at the 500-year discharge. Abutment scour ranged from 6.8 to $8.1 \mathrm{ft}$ at the right abutment and from 10.1 to $11.0 \mathrm{ft}$ at the left abutment. The worst-case abutment scour occurred at the 500-year discharge. Additional information on scour depths and depths to armoring are included in the section titled "Scour Results". Scouredstreambed elevations, based on the calculated scour depths, are presented in tables 1 and 2. A cross-section of the scour computed at the bridge is presented in figure 8 . Scour depths were calculated assuming an infinite depth of erosive material and a homogeneous particlesize distribution.

It is generally accepted that the Froehlich equation (abutment scour) gives "excessively conservative estimates of scour depths" (Richardson and Davis, 1995, p. 47). Usually, computed scour depths are evaluated in combination with other information including (but not limited to) historical performance during flood events, the geomorphic stability assessment, existing scour protection measures, and the results of the hydraulic analyses. Therefore, scour depths adopted by VTAOT may differ from the computed values documented herein. 


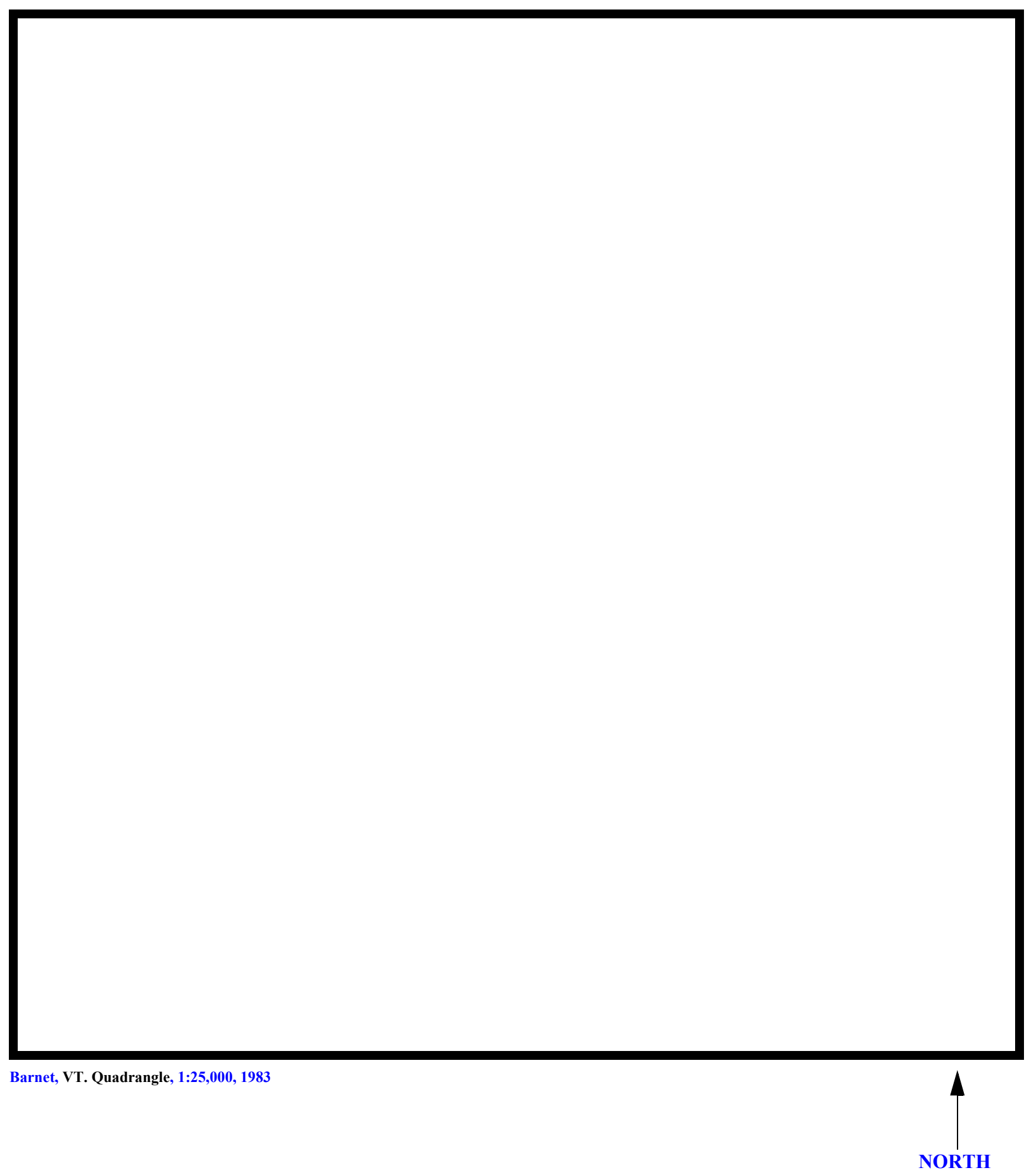

Figure 1. Location of study area on USGS 1:25,000 scale map. 
Figure 2. Location of study area on Vermont Agency of Transportation town highway map. 

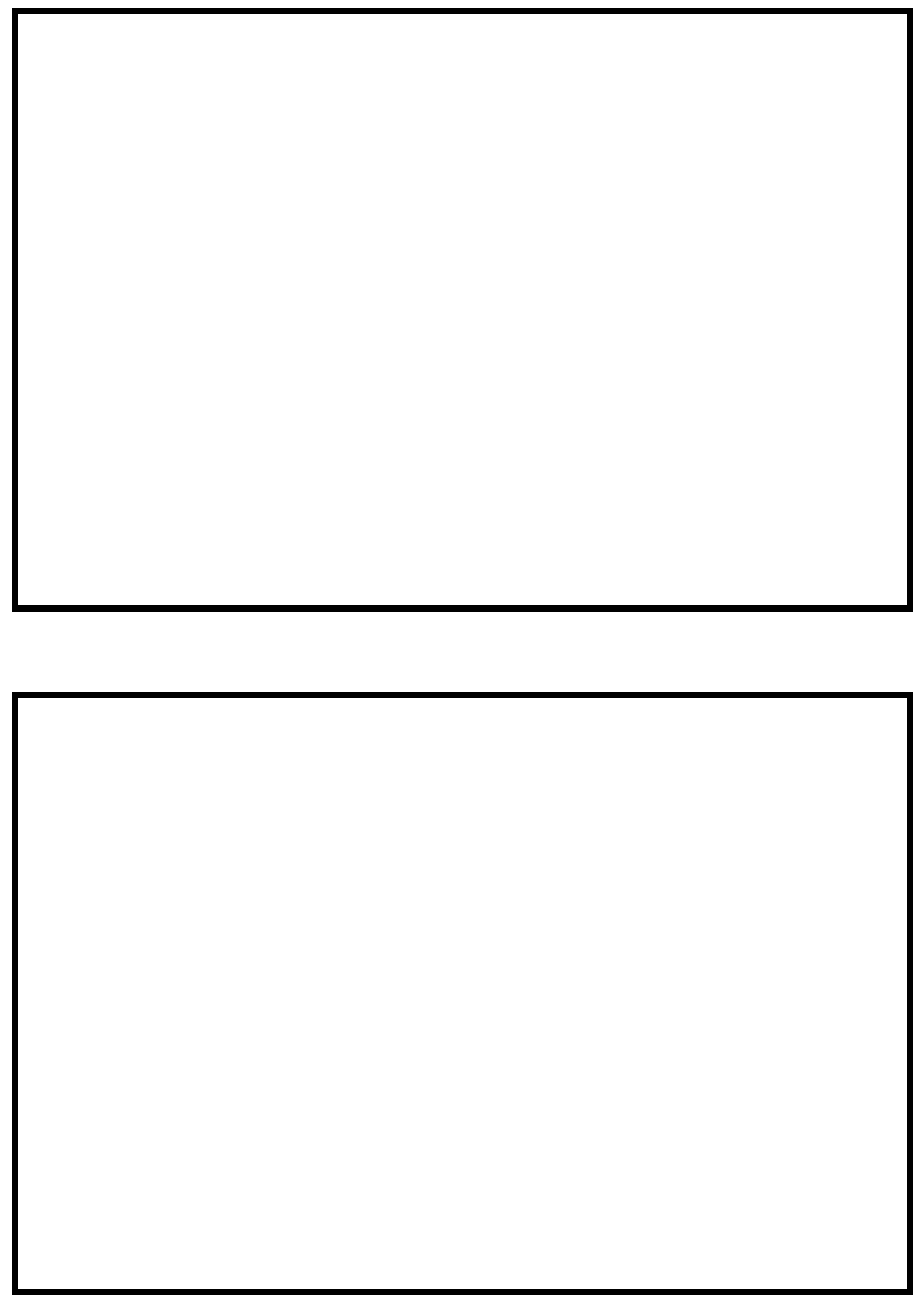

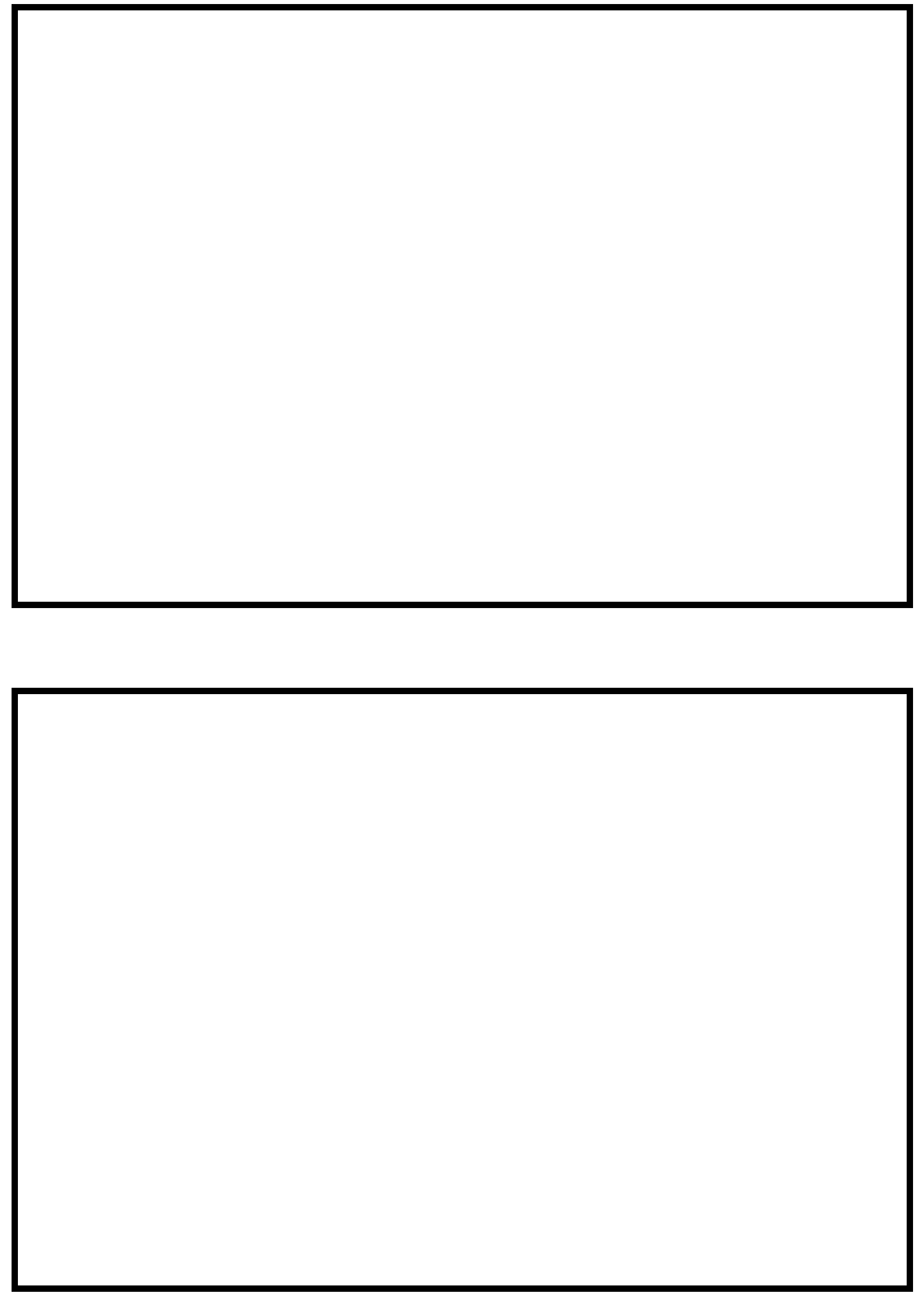


\section{LEVEL II SUMMARY}

\begin{tabular}{llllll} 
Structure Number & \multicolumn{2}{c}{ BRNETH00810042 } & Stream & \multicolumn{2}{c}{ Stevens River } \\
& Road & TH81 & District & 7 \\
County & Caledonia & Roann
\end{tabular}

\section{Description of Bridge}

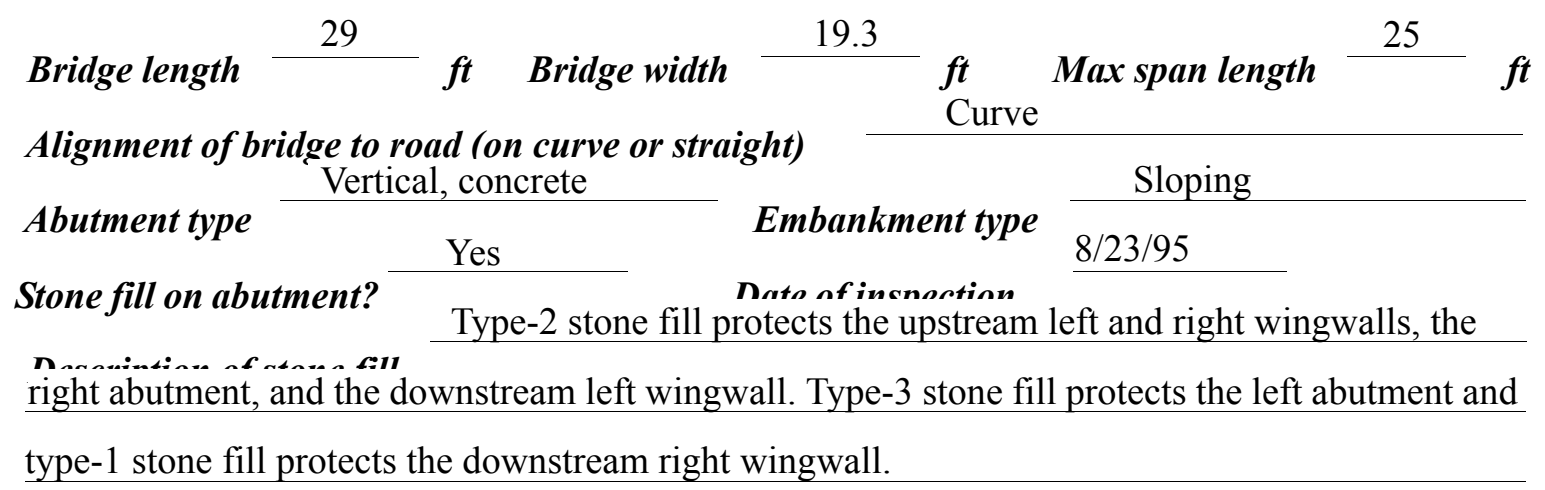

The abutments and wingwalls are concrete. There are

no reports of undermining or exposed footings.

\begin{tabular}{|c|c|c|}
\hline & Yes & 15 \\
\hline Is bridge skewed to flood flow according to Yes ' survey? & $A_{t}$ & \\
\hline
\end{tabular}

Debris accumulation on bridge at time of Level I or Level II site visit:

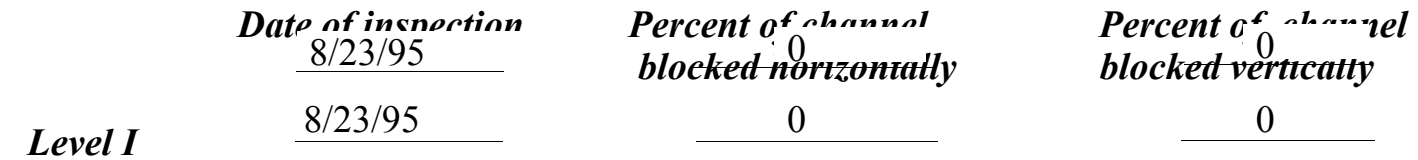

Level II There is a moderate potential for debris. There are a lot of trees and brush on the banks that could get caught in the stone fill under the bridge.

Potential for debris

There is a bedrock outcrop under the right abutment and the stone fill along the left abutment Doscriho anv, foaturos noar ar at tho hridoo that mav, affort flow, (includo ahsorvation dato) protrudes into the channel as observed on 8/23/95. 


\section{Description of the Geomorphic Setting}

General topography The channel is located in a moderate relief valley and has a narrow flood plain and moderately sloping valley sides.

Geomorphic conditions at bridge site: downstream (DS), upstream (US)

Date of inspection $\quad 8 / 23 / 95$

DS left: $\quad$ Steep channel bank to mildly sloped overbank

DS right: $\quad$ Moderate sloping channel bank to mildly sloped overbank

US left: $\quad$ Steep channel bank to moderately sloped overbank

US right: $\quad$ Steep channel bank

\section{Description of the Channel}

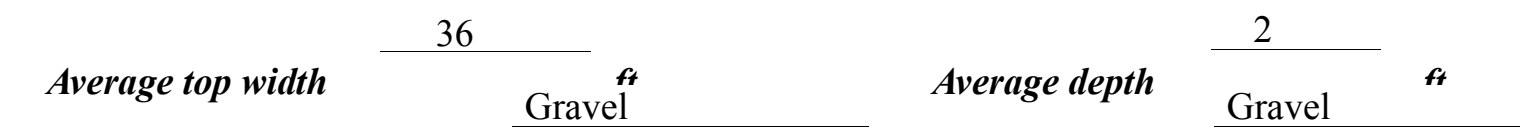

Predominant bed material

Bank material

The stream is

perennial and straight with non-alluvial channel boundaries and narrow point bars.

$8 / 23 / 95$
Vegetative col

DS left: $\quad$ Small trees with some shrubs and brush

DS right: $\quad$ Grass and brush with a few trees

US left: $\quad$ Shrubs, brush, and small trees.

US right: $\quad$ Yes

Do banks appear stable? -

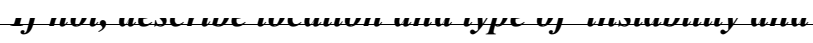

date of observatton.

A pile of debris, mostly

branches and leaves, was observed on 8/23/95 across the channel downstream of the bridge. Describe any obstructions in channel and date of observation.

The stone fill on the right bank upstream also protrudes into the channel. 


\section{Hydrology}

Drainage area $\stackrel{20.7}{m_{i}{ }^{2}}$

Percentage of drainage area in physiographic provinces: (approximate)

Physiographic province/section New England/New England Upland
Percent of drainage area 100

Is drainage area considered rural or urban?

Rural

urbanization: None as of 8/23/95

Is there a USGS gage on the stream of interest?

No

USGS gage description --

USGS gage number

Gage drainage area $\mathrm{mi}^{2}$

Describe any significant

Yes

Is there a lake/p About one third of the drainage area above this site is occupied by Harvey

Lake.

\begin{tabular}{|c|c|c|}
\hline 2,880 & Calculated Discharges & 4,000 \\
\hline & $Q 50$ & \\
\hline
\end{tabular}

The 100-year discharge is from a drainage area

relationship $[(20.7 / 23$.0)exp0.67/with the 100-year discharge at the confluence of Peacham

Hollow Brook with Stevens River from the Flood Insurance Study for the town of Barnet, VT

(FEMA, May 1988). The confluence is downstream of this site and Stevens River has a drainage area of 23.0 square miles above the confluence. The 500-year discharge was inferred based on a range of values defined by flood frequency curves developed from several empirical methods (Benson, 1962; Johnson and Tasker, 1974; FHWA, 1983; Potter, 1957a\&b; Talbot, 1887). Each curve was extended graphically to the 500 -year event. 


\section{Description of the Water-Surface Profile Model (WSPRO) Analysis}

Datum for WSPRO analysis (USGS survey, sea level, VTAOT plans)

USGS survey

Datum tie between USGS survey and VTAOT plans

None

Description of reference marks used to determine USGS datum. $\quad$ RM1 is a chiseled

square on top of the left abutment at the upstream end where it meets the wingwall (elev. 500.31

$\mathrm{ft}$, arbitrary survey datum). RM2 is a chiseled " $\mathrm{X}$ " on top of the right abutment at the upstream

end where it meets the wingwall (elev. $500.30 \mathrm{ft}$, arbitrary survey datum).

\section{Cross-Sections Used in WSPRO Analysis}

\begin{tabular}{cccl}
\hline${ }^{1}$ Cross-section & $\begin{array}{c}\text { Section } \\
\text { Reference } \\
\text { Distance } \\
\text { (SRD) } \text { in feet }\end{array}$ & $\begin{array}{c}{ }^{2} \text { Cross-section } \\
\text { development }\end{array}$ & \multicolumn{1}{c}{ Comments } \\
\hline EXITX & -32 & 1 & $\begin{array}{l}\text { Exit section } \\
\text { Downstream Full-valley } \\
\text { section (Templated from } \\
\text { EXITX) }\end{array}$ \\
FULLV & 0 & 2 & $\begin{array}{l}\text { Bridge section } \\
\text { Road Grade section }\end{array}$ \\
RDWHY & 0 & 1 & $\begin{array}{l}\text { Modelled Approach sec- } \\
\text { tion (Templated from } \\
\text { APTEM) }\end{array}$ \\
APPRO & 10 & 1 & $\begin{array}{l}\text { Approach section as sur- } \\
\text { veyed (Used as a tem- } \\
\text { plate) }\end{array}$ \\
\hline
\end{tabular}

${ }^{1}$ For location of cross-sections see plan-view sketch included with Level I field form, Appendix E. For more detail on how cross-sections were developed see WSPRO input file. 


\section{Data and Assumptions Used in WSPRO Model}

Hydraulic analyses of the reach were done by use of the Federal Highway Administration's WSPRO step-backwater computer program (Shearman and others, 1986, and Shearman, 1990). The analyses reported herein reflect conditions existing at the site at the time of the study. Furthermore, in the development of the model it was necessary to assume no accumulation of debris or ice at the site. Results of the hydraulic model are presented in the Bridge Hydraulic Summary, appendix B, and figure 7.

Channel roughness factors (Manning's " $n$ ") used in the hydraulic model were estimated using field inspections at each cross section following the general guidelines described by Arcement and Schneider (1989). Final adjustments to the values were made during the modelling of the reach. Channel " $n$ " values for the reach ranged from 0.050 to 0.055 , and overbank " $\mathrm{n}$ " values ranged from 0.035 to 0.050 .

Normal depth at the exit section (EXITX) was assumed as the starting water surface. This depth was computed by use of the slope-conveyance method outlined in the user's manual for WSPRO (Shearman, 1990). The slope used was $0.0100 \mathrm{ft} / \mathrm{ft}$, which was estimated from topographic map contour lines(U.S. Geological Survey, 1983).

The surveyed approach section (APTEM) was moved along the approach channel slope $(0.007 \mathrm{ft} / \mathrm{ft})$ to establish the modelled approach section (APPRO), one bridge length upstream of the upstream face as recommended by Shearman and others (1986). This location provides a consistent method for determining scour variables. 


\section{Bridge Hydraulics Summary}

\begin{tabular}{llll} 
Average bridge embankment elevation & 501.2 & $f t$ \\
\cline { 3 - 3 } Average low steel elevation & 498.5 & $\boldsymbol{f t}$
\end{tabular}

100-year discharge $\quad 2,880 \quad \mathrm{ft}^{3} / \mathrm{s}$

Water-surface elevation in bridge opening $\quad 498.5 \quad f t$

Road overtopping? ___ Yes Discharge over road __ $774 \quad \mathrm{ft}^{3} / \mathrm{s}$

Area of flow in bridge opening $\quad 192 \quad \mathrm{ft}^{2}$

Average velocity in bridge opening $11.0 \mathrm{ft} / \mathrm{s}$

Maximum WSPRO tube velocity at bridge $\quad 13.7 \mathrm{ft} / \mathrm{s}$

Water-surface elevation at Approach section with bridge $\quad 502.0$

Water-surface elevation at Approach section without bridge $\quad 497.6$

Amount of backwater caused by bridge

4.4 it

500-year discharge $\quad 4,000 \quad \mathrm{ft}^{3} / \mathrm{s}$

Water-surface elevation in bridge opening

$498.5 \mathrm{ft}$

Road overtopping? ___ Yes Discharge over road __ 1,610 $\mathrm{ft}^{3} / \mathrm{s}$

Area of flow in bridge opening $\quad 192 \quad \mathrm{ft}^{2}$

Average velocity in bridge opening $12.4 \mathrm{ft} / \mathrm{s}$

Maximum WSPRO tube velocity at bridge 15.4 's

Water-surface elevation at Approach section with bridge

Water-surface elevation at Approach section without bridge

Amount of backwater caused by bridge 3.2 , $t$

502.7

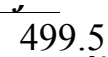

Incipient overtopping discharge $\quad 1,670 \mathrm{ft}^{3} / \mathrm{s}$

Water-surface elevation in bridge opening $498.5 \quad t$

Area of flow in bridge opening

$192 \mathrm{ft}^{2}$

Average velocity in bridge opening

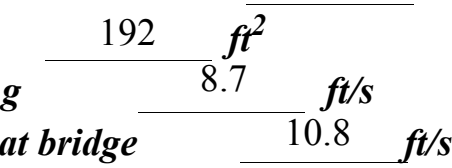

Water-surface elevation at Approach section with bridge

Water-surface elevation at Approach section without bridge

500.2

Amount of backwater caused by bridge

4.8 . $t$

495.4 


\section{Scour Analysis Summary}

\section{Special Conditions or Assumptions Made in Scour Analysis}

Scour depths were computed using the general guidelines described in Hydraulic Engineering Circular 18 (Richardson and Davis, 1995). Scour depths were calculated assuming an infinite depth of erosive material and a homogeneous particle-size distribution. The results of the scour analysis are presented in tables 1 and 2 and the scour depths are presented graphically in figure 8 .

At this site, the 100-year and incipient roadway-overtopping discharges resulted in unsubmerged orifice flow. The 500-year discharge resulted in submerged orifice flow. Contraction scour at bridges with orifice flow is best estimated by use of the Chang pressureflow scour equation (oral communication, J. Sterling Jones, October 4, 1996). Thus, contraction scour was computed by use of the Chang equation (Richardson and Davis, 1995, p. 145-146). The streambed armoring depths computed suggest that armoring will not limit the depth of contraction scour.

For comparison, contraction scour for the discharges resulting in orifice flow was also computed by use of the Laursen clear-water contraction scour equation and the Umbrell pressure-flow equation (Richardson and Davis, 1995, p. 144). The results are presented in appendix F. Furthermore, for those discharges resulting in unsubmerged orifice flow, contraction scour was computed by substituting estimates for the depth of flow at the downstream bridge face in the contraction scour equations. Results with respect to these substitutions also are provided in appendix F.

Abutment scour for the right abutment was computed by use of the Froehlich equation (Richardson and Davis, 1995, p. 48, equation 28). Variables for the Froehlich equation include the Froude number of the flow approaching the embankments, the length of the embankment blocking flow, and the depth of flow approaching the embankment less any roadway overtopping.

Scour at the left abutment was computed by use of the HIRE equation (Richardson and Davis, 1995, p. 49, equation 29) because the HIRE equation is recommended when the length to depth ratio of the embankment blocking flow exceeds 25 . The variables used by the HIRE abutment-scour equation are defined the same as those defined for the Froehlich abutment-scour equation. 


\section{Scour Results}

Contraction scour:

Main channel

Live-bed scour

Clear-water scour

Depth to armoring

Left overbank

Right overbank

Local scour:

Abutment scour

Left abutment

Right abutment

Pier scour

Pier 1

Pier 2

Pier 3
11.0

$7.4-$
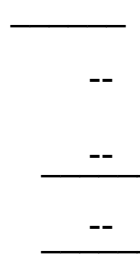

Incipient overtopping discharge

(Scour depths in feet) 


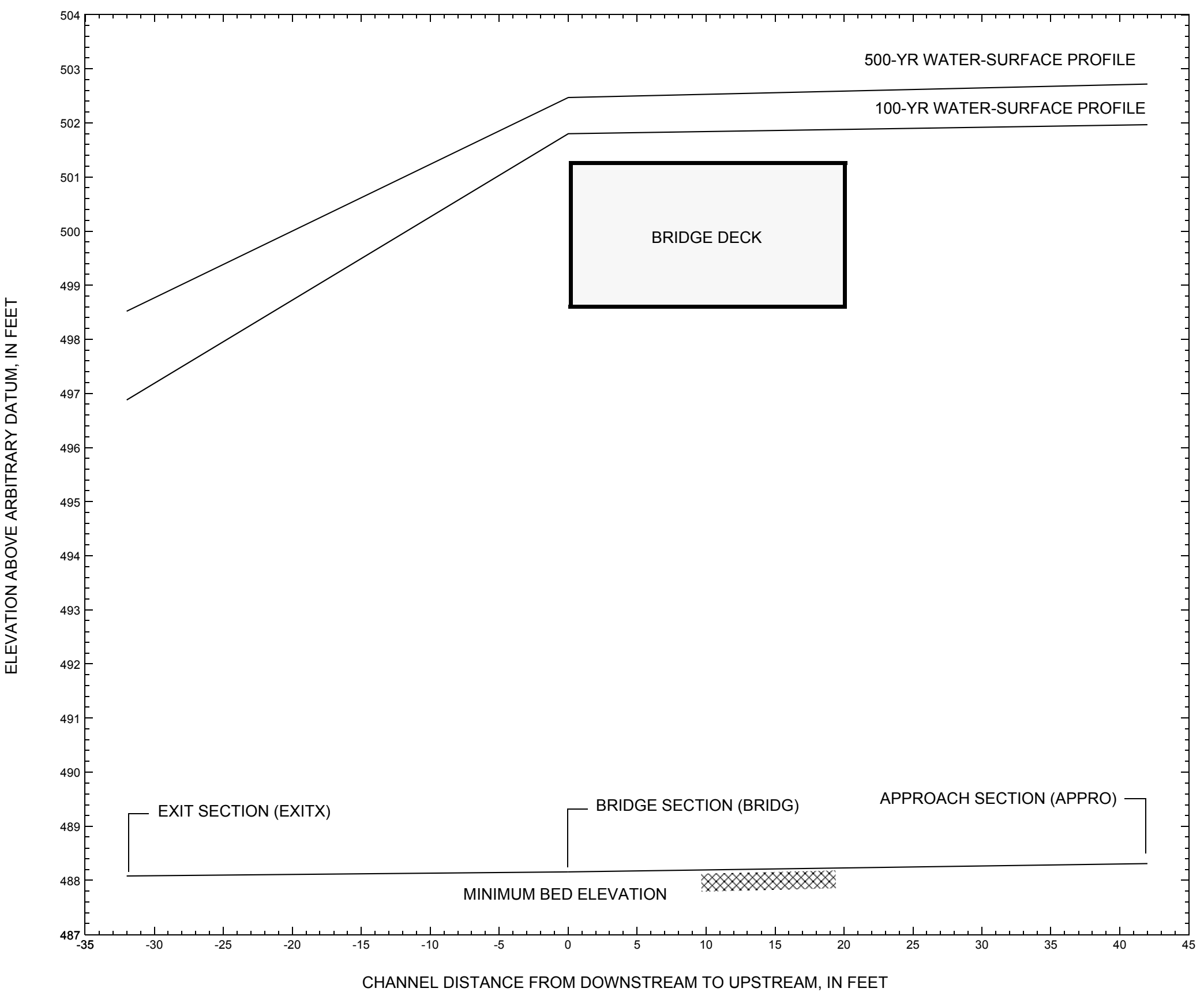

Figure 7. Water-surface profiles for the 100- and 500-year discharges at structure BRNETH00810042 on Town Highway 81, crossing the Stevens River, Barnet, Vermont. 


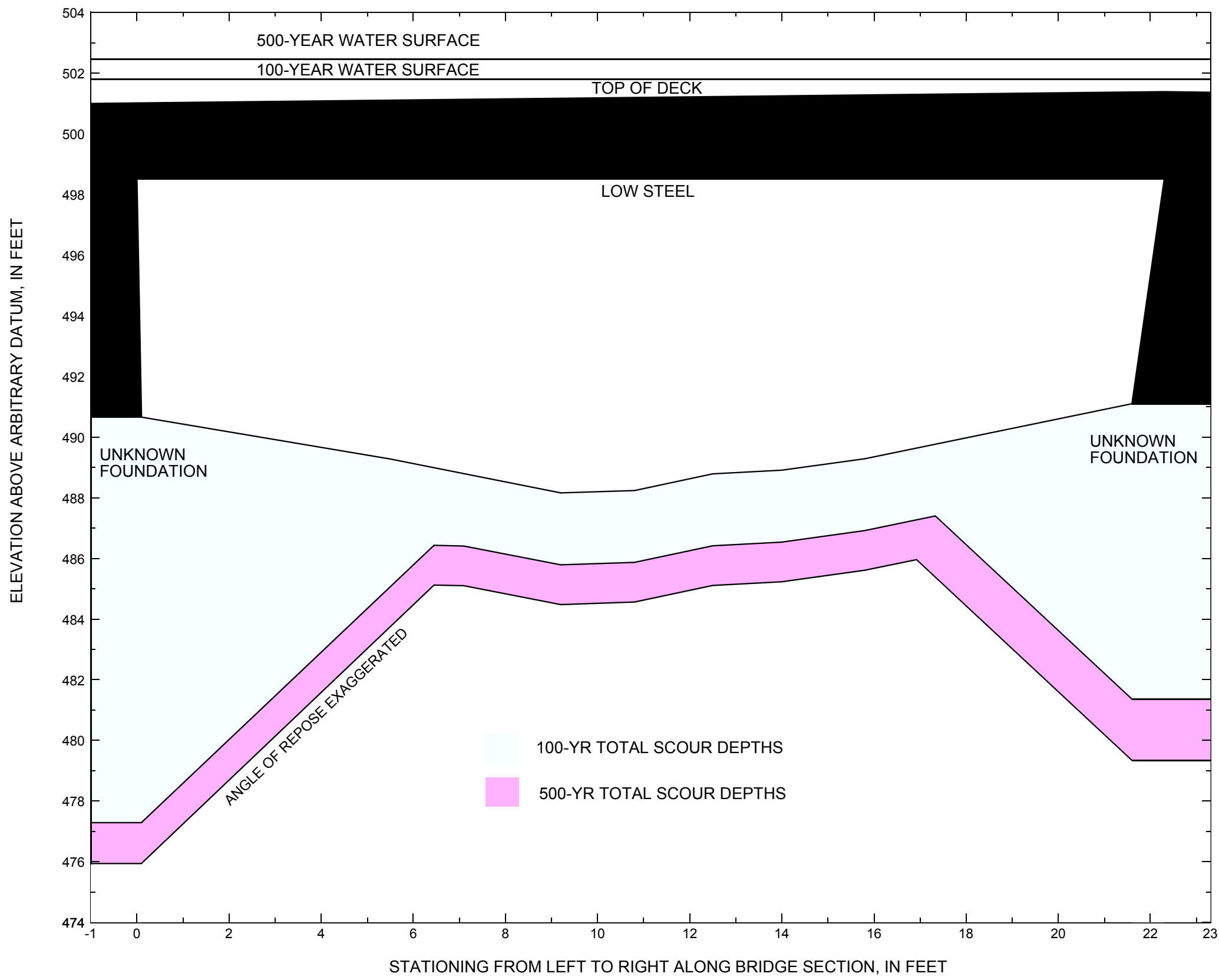

Figure 8. Scour elevations for the 100- and 500-year discharges at structure BRNETH00810042 on Town Highway 81, crossing the Stevens River, Barnet, Vermont. 
Table 1. Remaining footing/pile depth at abutments for the 100-year discharge at structure BRNETH00810042 on Town Highway 81, crossing the Stevens River, Barnet, Vermont.

[VTAOT, Vermont Agency of Transportation; --, no data]

\begin{tabular}{|c|c|c|c|c|c|c|c|c|c|c|c|}
\hline Description & Station $^{1}$ & $\begin{array}{l}\text { VTAOT } \\
\text { minimum } \\
\text { low-chord } \\
\text { elevation } \\
\text { (feet) }\end{array}$ & $\begin{array}{l}\text { Surveyed } \\
\text { minimum } \\
\text { low-chord } \\
\text { elevation }{ }^{2} \\
\text { (feet) }\end{array}$ & $\begin{array}{c}\text { Bottom of } \\
\text { footing/pile } \\
\text { elevation }{ }^{2} \\
\text { (feet) }\end{array}$ & $\begin{array}{c}\text { Channel } \\
\text { elevation at } \\
\text { abutment/ } \\
\text { pier }^{2} \\
\text { (feet) }\end{array}$ & $\begin{array}{l}\text { Contraction } \\
\text { scour depth } \\
\text { (feet) }\end{array}$ & $\begin{array}{l}\text { Abutment } \\
\text { scour } \\
\text { depth } \\
\text { (feet) }\end{array}$ & $\begin{array}{l}\text { Pier } \\
\text { scour } \\
\text { depth } \\
\text { (feet) }\end{array}$ & $\begin{array}{l}\text { Depth of } \\
\text { total scour } \\
\text { (feet) }\end{array}$ & $\begin{array}{c}\text { Elevation of } \\
\text { scour }^{2} \\
\text { (feet) }\end{array}$ & $\begin{array}{c}\text { Remaining } \\
\text { footing/pile } \\
\text { depth } \\
\text { (feet) }\end{array}$ \\
\hline \multicolumn{12}{|c|}{100 -year discharge is 2,880 cubic-feet per second } \\
\hline Left abutment & 0.0 & -- & 498.5 & -- & 490.7 & 2.4 & 11.0 & -- & 13.4 & 477.3 & -- \\
\hline Right abutment & 22.3 & -- & 498.5 & -- & 491.1 & 2.4 & 7.4 & -- & 9.8 & 481.3 & -- \\
\hline
\end{tabular}

1.Measured along the face of the most constricting side of the bridge.

2.Arbitrary datum for this study.

Table 2. Remaining footing/pile depth at abutments for the 500-year discharge at structure BRNETH00810042 on Town Highway 81, crossing the Stevens River, Barnet, Vermont.

[VTAOT, Vermont Agency of Transportation; --, no data]

\begin{tabular}{|c|c|c|c|c|c|c|c|c|c|c|c|}
\hline Description & Station $^{1}$ & $\begin{array}{l}\text { VTAOT } \\
\text { minimum } \\
\text { low-chord } \\
\text { elevation } \\
\text { (feet) }\end{array}$ & $\begin{array}{c}\text { Surveyed } \\
\text { minimum } \\
\text { low-chord } \\
\text { elevation } \\
\text { (feet) }\end{array}$ & $\begin{array}{c}\text { Bottom of } \\
\text { footing/pile } \\
\text { elevation } \\
\text { (feet) }\end{array}$ & $\begin{array}{c}\text { Channel } \\
\text { elevation at } \\
\text { abutment/ } \\
\text { pier }^{2} \\
\text { (feet) }\end{array}$ & $\begin{array}{l}\text { Contraction } \\
\text { scour depth } \\
\text { (feet) }\end{array}$ & $\begin{array}{c}\text { Abutment } \\
\text { scour } \\
\text { depth } \\
\text { (feet) }\end{array}$ & $\begin{array}{l}\text { Pier } \\
\text { scour } \\
\text { depth } \\
\text { (feet) }\end{array}$ & $\begin{array}{l}\text { Depth of } \\
\text { total scour } \\
\text { (feet) }\end{array}$ & $\begin{array}{c}\text { Elevation of } \\
\text { scour }^{2} \\
\text { (feet) }\end{array}$ & $\begin{array}{c}\text { Remaining } \\
\text { footing/pile } \\
\text { depth } \\
\text { (feet) }\end{array}$ \\
\hline \multicolumn{12}{|c|}{500 -year discharge is 4,000 cubic-feet per second } \\
\hline Left abutment & 0.0 & -- & 498.5 & -- & 490.7 & 3.7 & 11.0 & -- & 14.7 & 476.0 & -- \\
\hline Right abutment & 22.3 & -- & 498.5 & -- & 491.1 & 3.7 & 8.1 & -- & 11.8 & 479.3 & -- \\
\hline
\end{tabular}

1.Measured along the face of the most constricting side of the bridge.

2.Arbitrary datum for this study. 


\section{SELECTED REFERENCES}

Arcement, G.J., Jr., and Schneider, V.R., 1989, Guide for selecting Manning's roughness coefficients for natural channels and flood plains:

U.S. Geological Survey Water-Supply Paper 2339, 38 p.

Barnes, H.H., Jr., 1967, Roughness characteristics of natural channels: U.S. Geological Survey Water-Supply Paper 1849,213 p.

Benson, M. A., 1962, Factors Influencing the Occurrence of Floods in a Humid Region of Diverse Terrain: U.S. Geological Survey WaterSupply Paper 1580-B, 64 p.

Brown, S.A. and Clyde, E.S., 1989, Design of riprap revetment: Federal Highway Administration Hydraulic Engineering Circular No. 11, Publication FHWA-IP-89-016, 156 p.

Federal Emergency Management Agency, 1988, Flood Insurance Study, Town of Barnet, Caledonia County, Vermont: Washington, D.C., May 1988.

Federal Highway Administration, 1983, Runoff estimates for small watersheds and development of sound design: Federal Highway Administration Report FHWA-RD-77-158.

Federal Highway Administration, 1993, Stream Stability and Scour at Highway Bridges: Participant Workbook: Federal Highway Administration Report FHWA-HI-91-011.

Froehlich, D.C., 1989, Local scour at bridge abutments in Ports, M.A., ed., Hydraulic Engineering--Proceedings of the 1989 National Conference on Hydraulic Engineering: New York, American Society of Civil Engineers, p. 13-18.

Hayes, D.C.,1993, Site selection and collection of bridge-scour data in Delaware, Maryland, and Virginia: U.S. Geological Survey WaterResources Investigation Report 93-4017, 23 p.

Interagency Advisory Committee on Water Data, 1982, Guidelines for determining flood flow frequency: U.S. Geological Survey, Bulletin 17B of the Hydrology Subcommittee, 190 p.

Johnson, C.G. and Tasker, G.D.,1974, Progress report on flood magnitude and frequency of Vermont streams: U.S. Geological Survey OpenFile Report 74-130, 37 p.

Lagasse, P.F., Schall, J.D., Johnson, F., Richardson, E.V., Chang, F., 1995, Stream Stability at Highway Structures: Federal Highway Administration Hydraulic Engineering Circular No. 20, Publication FHWA-IP-90-014, 144 p.

Laursen, E.M., 1960, Scour at bridge crossings: Journal of the Hydraulics Division, American Society of Civil Engineers, v. 86, no. HY2, p. 39-53.

Potter, W. D., 1957a, Peak rates of runoff in the Adirondack, White Mountains, and Maine woods area, Bureau of Public Roads

Potter, W. D., 1957b, Peak rates of runoff in the New England Hill and Lowland area, Bureau of Public Roads

Richardson, E.V. and Davis, S.R., 1995, Evaluating scour at bridges: Federal Highway Administration Hydraulic Engineering Circular No. 18, Publication FHWA-IP-90-017, 204 p.

Richardson, E.V., Simons, D.B., and Julien, P.Y., 1990, Highways in the river environment: Federal Highway Administration Publication FHWA-HI-90-016.

Ritter, D.F., 1984, Process Geomorphology: W.C. Brown Co., Debuque, Iowa, 603 p.

Shearman, J.O., 1990, User's manual for WSPRO--a computer model for water surface profile computations: Federal Highway Administration Publication FHWA-IP-89-027, 187 p.

Shearman, J.O., Kirby, W.H., Schneider, V.R., and Flippo, H.N., 1986, Bridge waterways analysis model; research report: Federal Highway Administration Publication FHWA-RD-86-108, 112 p.

Talbot, A.N., 1887, The determination of water-way for bridges and culverts.

U.S. Geological Survey, 1983, Barnet, Vermont 7.5 by 15 Minute Series quadrangle map: U.S. Geological Survey Topographic Maps, Scale $1: 25,000$. 


\section{APPENDIX A: \\ WSPRO INPUT FILE}


WSPRO INPUT FILE (continued)

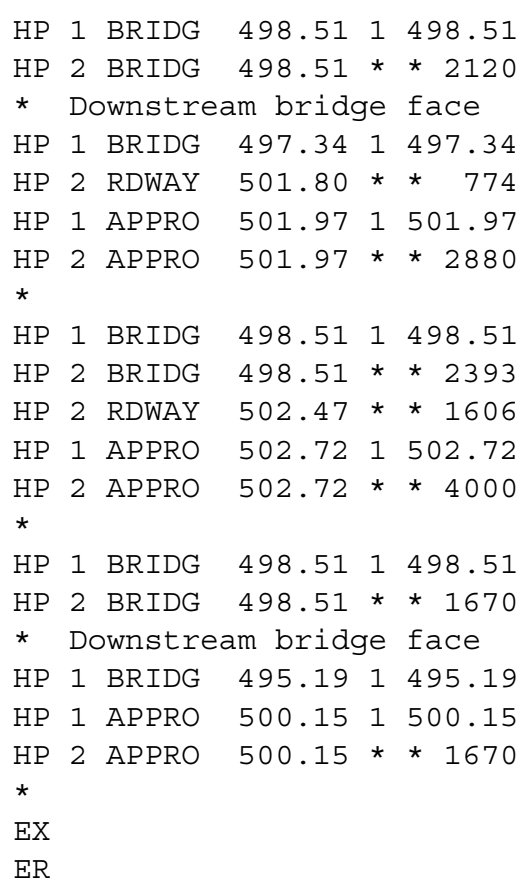




\section{APPENDIX B: \\ WSPRO OUTPUT FILE}




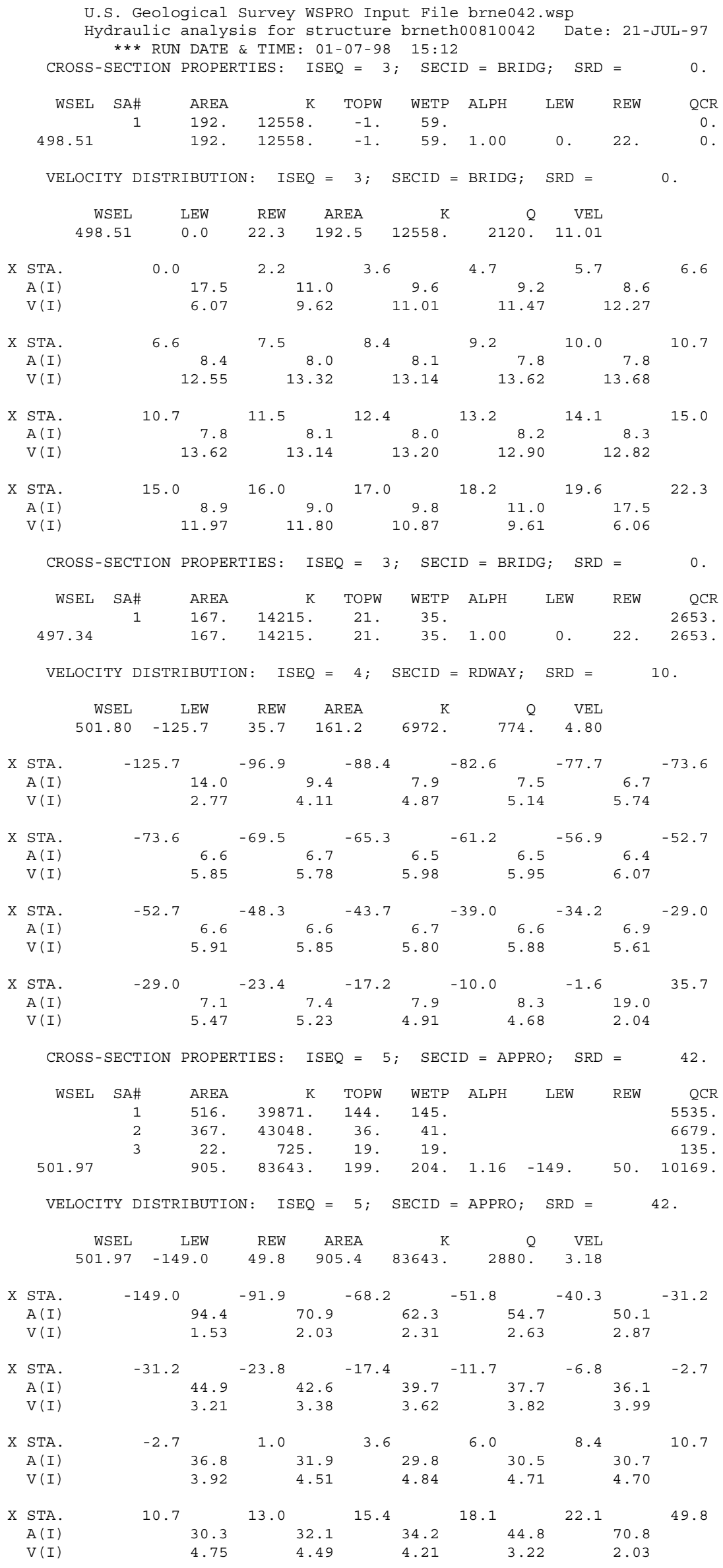


WSPRO OUTPUT FILE (continued)

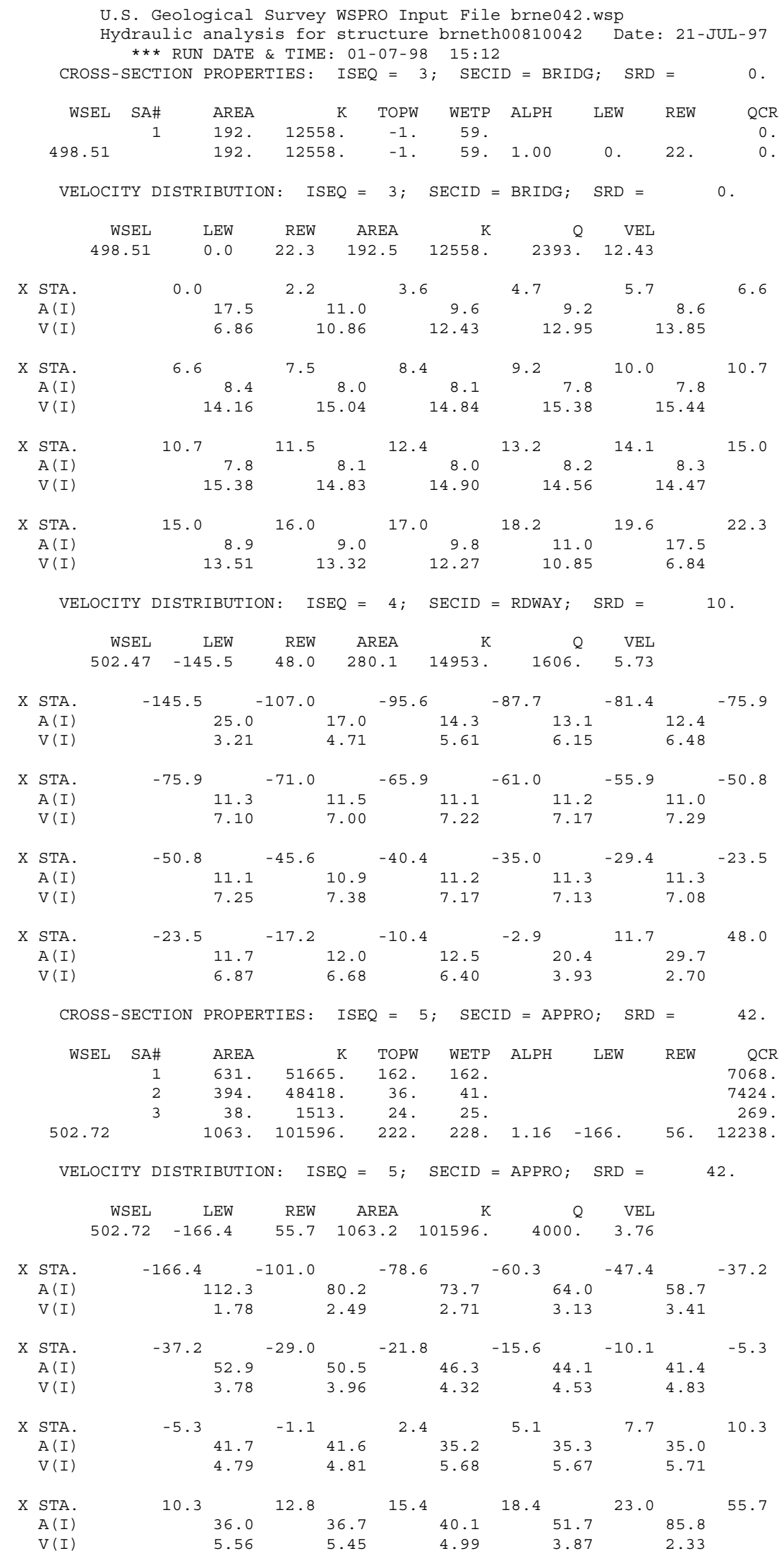


WSPRO OUTPUT FILE (continued)

\begin{tabular}{|c|c|c|c|c|c|c|c|c|c|c|c|c|}
\hline & $\begin{array}{r}\text { Hydr } \\
\star\end{array}$ & $\begin{array}{l}\text { aulic } \\
* * \text { RUN }\end{array}$ & $\begin{array}{l}\text { analysi } \\
\text { DATE }\end{array}$ & $\begin{array}{l}\text { is for } \\
\& \text { TIME }\end{array}$ & struc & $\begin{array}{l}\text { lcture } \\
07-98\end{array}$ & $\begin{array}{r}\text { brneth } \\
15: 12\end{array}$ & $\begin{array}{l}\text { h00810042 } \\
2\end{array}$ & & Date & $: 21-3$ & JUL - 97 \\
\hline & CROSS-SEC & CTION & PROPERT & TIES: & ISEQ & $=3$ & SECI & $I D=B R I D$ & DG ; & SRD & $=$ & 0. \\
\hline & WSEL SE & A\# & AREA & & K & TOPW & WETP & ALPH & LE & & REW & QCR \\
\hline & & 1 & 192. & 1255 & 8. & -1 & 59. & & & & & 0. \\
\hline & 498.51 & & 192. & 12558 & 8. & -1 & 59. & 1.00 & & o. & 22. & 0 . \\
\hline & VELOCITY & DISTR & IBUTION & ISI & $\mathrm{EQ}=$ & $3 ;$ & SECID $=$ & $=$ BRIDG; & & $\mathrm{RD}=$ & & 0 . \\
\hline & WSEI & & LEW & REW & $\mathrm{ARI}$ & $E A$ & K & $\varnothing$ & Q & VEL & & \\
\hline & 498.51 & & 0.0 & 22.3 & 192 & .5 & 12558 . & 1670. & & 8.68 & & \\
\hline X & STA. & 0.0 & & 2.2 & & 3.6 & & 4.7 & & 5.7 & & 6.6 \\
\hline & $A(I)$ & & 17.5 & & 11.0 & & 9.6 & 9. & .2 & & 8.6 & \\
\hline & $V(I)$ & & 4.78 & & 7.58 & & 8.67 & 9.0 & & & 9.67 & \\
\hline $\mathrm{x}$ & STA. & 6.6 & & 7.5 & & 8.4 & & 9.2 & & 10.0 & & 10.7 \\
\hline & $A(I)$ & & 8.4 & & 8.0 & & 8.1 & 7. & .8 & & 7.8 & \\
\hline & $V(I)$ & & 9.88 & & 0.49 & & 10.35 & 10.7 & & & 10.77 & \\
\hline $\mathrm{x}$ & STA. & 10.7 & & 11.5 & & 12.4 & & 13.2 & & 14.1 & & 15.0 \\
\hline & $A(I)$ & & 7.8 & & 8.1 & & 8.0 & 8. & .2 & & 8.3 & \\
\hline & $V(I)$ & & 10.73 & & 0.35 & & 10.40 & 10.1 & & & 10.10 & \\
\hline $\mathrm{X}$ & STA. & 15.0 & & 16.0 & & 17.0 & & 18.2 & & 19.6 & & 22.3 \\
\hline & $\mathrm{A}(\mathrm{I})$ & & 8.9 & & 9.0 & & 9.8 & 11. & & & 17.5 & \\
\hline & $\mathrm{V}(\mathrm{I})$ & & 9.43 & & 9.29 & & 8.56 & 7.5 & & & 4.77 & \\
\hline & CROSS-SEC & CTION & PROPERT & TIES : & ISEQ & $=3$ & SECI & $I D=B R I D$ & DG ; & SRD & $=$ & 0 . \\
\hline & WSEL SF & A\# & AREA & & K & TOPW & WETP & ALPH & $\mathrm{LE}$ & $\mathrm{EW}$ & REW & $\mathrm{QCR}$ \\
\hline & & 1 & 121. & 9102 & 2 . & 21. & 30. & & & & & 1648 . \\
\hline & 495.19 & & 121. & 9102 & 2 . & 21. & 30. & 1.00 & & 0. & 22. & 1648. \\
\hline & CROSS-SEC & CTION & PROPERT & TIES : & ISEQ & $=5$ & SECI & $I D=A P P R$ & $\mathrm{RO}$ ； & SRD & $=$ & 42 . \\
\hline & WSEL SE & A\# & AREA & & $\mathrm{K}$ & TOPW & WETP & ALPH & LE & $\mathrm{EW}$ & REW & QCR \\
\hline & & 1 & 279 . & 1641 & & 117. & 118. & & & & & 2439. \\
\hline & & 2 & 302 . & 31092 & 2 . & 36. & 41. & & & & & 4983. \\
\hline & & 3 & 1. & & 4. & 4. & 4. & & & & & 3. \\
\hline & 500.15 & & 582. & 47522 & & 157. & 163. & 1.22 & -122 & & 35. & 5755. \\
\hline & VELOCITY & DISTR & IBUTION & ISI & $\mathrm{EQ}=$ & $5 ;$ & SECID $=$ & $=\mathrm{APPRO} ;$ & & $\mathrm{RD}=$ & & 42 . \\
\hline & WSEI & & LEW & REW & ARI & EA & $\mathrm{K}$ & & Q & VEL & & \\
\hline & 500.15 & -12 & 2.0 & 35.4 & 582 & .3 & 47522 & 1670. & & 2.87 & & \\
\hline $\mathrm{X}$ & STA. & -122.0 & & -52.4 & & -37.1 & & -27.0 & & -19.5 & & -13.4 \\
\hline & $A(I)$ & & 74.8 & & 46.2 & & 40.1 & 34. & & & 31.1 & \\
\hline & $V(I)$ & & 1.12 & & 1.81 & & 2.08 & 2.4 & & & 2.69 & \\
\hline $\mathrm{X}$ & STA. & -13.4 & & -8.3 & & -4.2 & & -1.0 & & 1.6 & & 3.5 \\
\hline & $\mathrm{A}(\mathrm{I})$ & & 29.0 & & 25.9 & & 24.1 & 23. & & & 19.9 & \\
\hline & $V(I)$ & & 2.88 & & 3.22 & & 3.47 & 3.5 & & & 4.20 & \\
\hline $\mathrm{X}$ & STA. & 3.5 & & 5.3 & & 7.1 & & 8.8 & & 10.5 & & 12.2 \\
\hline & $A(I)$ & & 19.0 & & 19.2 & & 19.2 & 19. & & & 19.6 & \\
\hline & $V(I)$ & & 4.39 & & 4.34 & & 4.35 & 4.3 & 36 & & 4.25 & \\
\hline $\mathrm{X}$ & STA. & 12.2 & & 13.9 & & 15.8 & & 18.0 & & 20.8 & & 35.4 \\
\hline & $A(I)$ & & 20.2 & & 21.5 & & 23.6 & 28. & .0 & & 43.8 & \\
\hline & $\mathrm{V}(\mathrm{I})$ & & 4.14 & & 3.89 & & 3.54 & 2.9 & 98 & & 1.91 & \\
\hline
\end{tabular}


WSPRO OUTPUT FILE (continued)

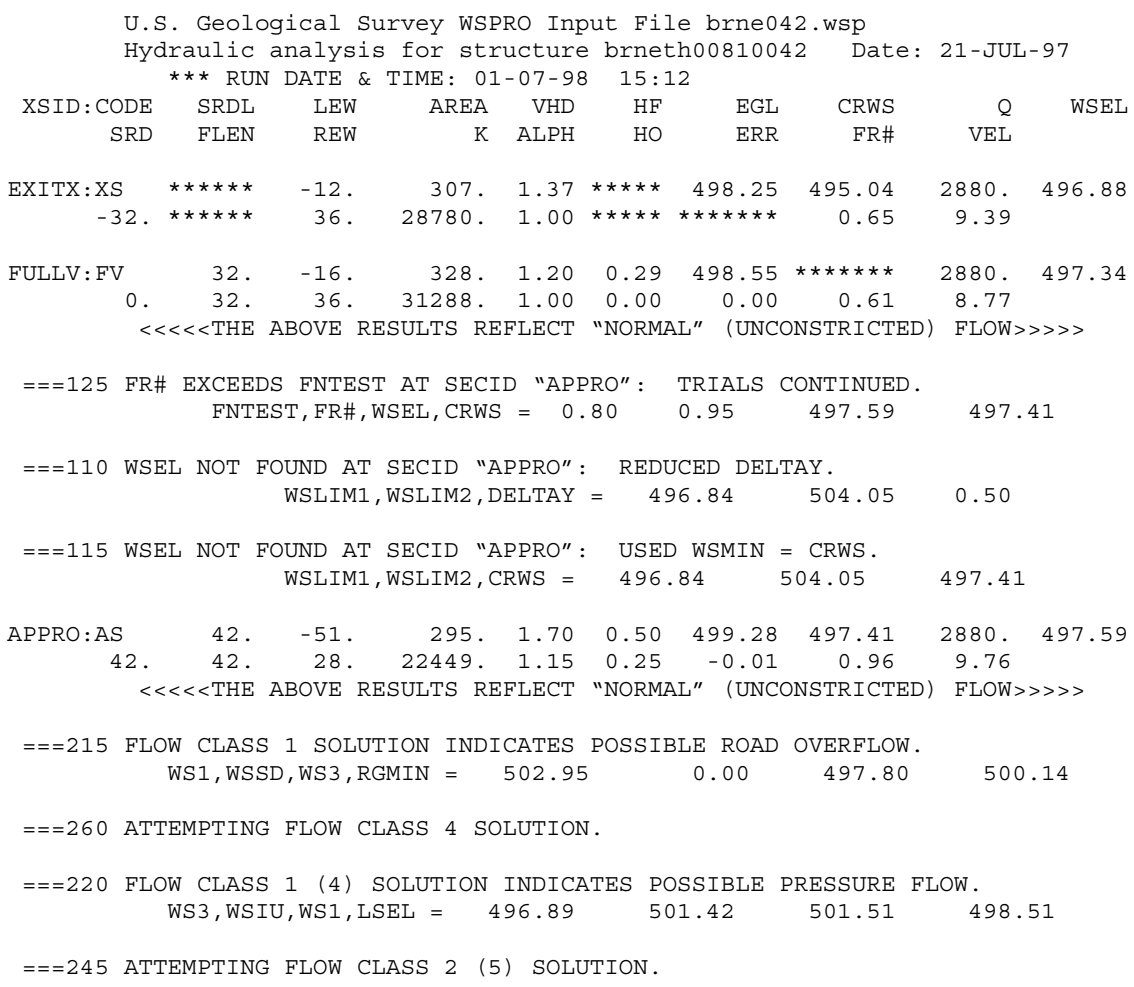

SECOND USER DEFINED TABLE.

$\begin{array}{lcrrrrrrrr}\text { XSID : CODE } & \text { CRWS } & \text { FR\# } & \text { YMIN } & \text { YMAX } & \text { HF } & \text { HO } & \text { VHD } & \text { EGL } & \text { WSEL } \\ \text { EXITX:XS } & 495.04 & 0.65 & 488.08 & 509.81 * * * * * * * * * * & 1.37 & 498.25 & 496.88 \\ \text { FULLV:FV } & * * * * * * * * & 0.61 & 488.11 & 509.84 & 0.29 & 0.00 & 1.20 & 498.55 & 497.34 \\ \text { BRIDG:BR } & 496.24 & 0.66 & 488.16 & 498.51 * * * * * * * * * * & 1.89 & 500.40 & 498.51 \\ \text { RDWAY:RG } & * * * * * * * * * * * * * * * * & 500.14 & 504.10 & 0.03 * * * * * * & 0.18 & 502.13 & 501.80 \\ \text { APPRO:AS } & 497.41 & 0.28 & 488.31 & 504.05 & 0.07 & 1.07 & 0.18 & 502.16 & 501.97\end{array}$


WSPRO OUTPUT FILE (continued)

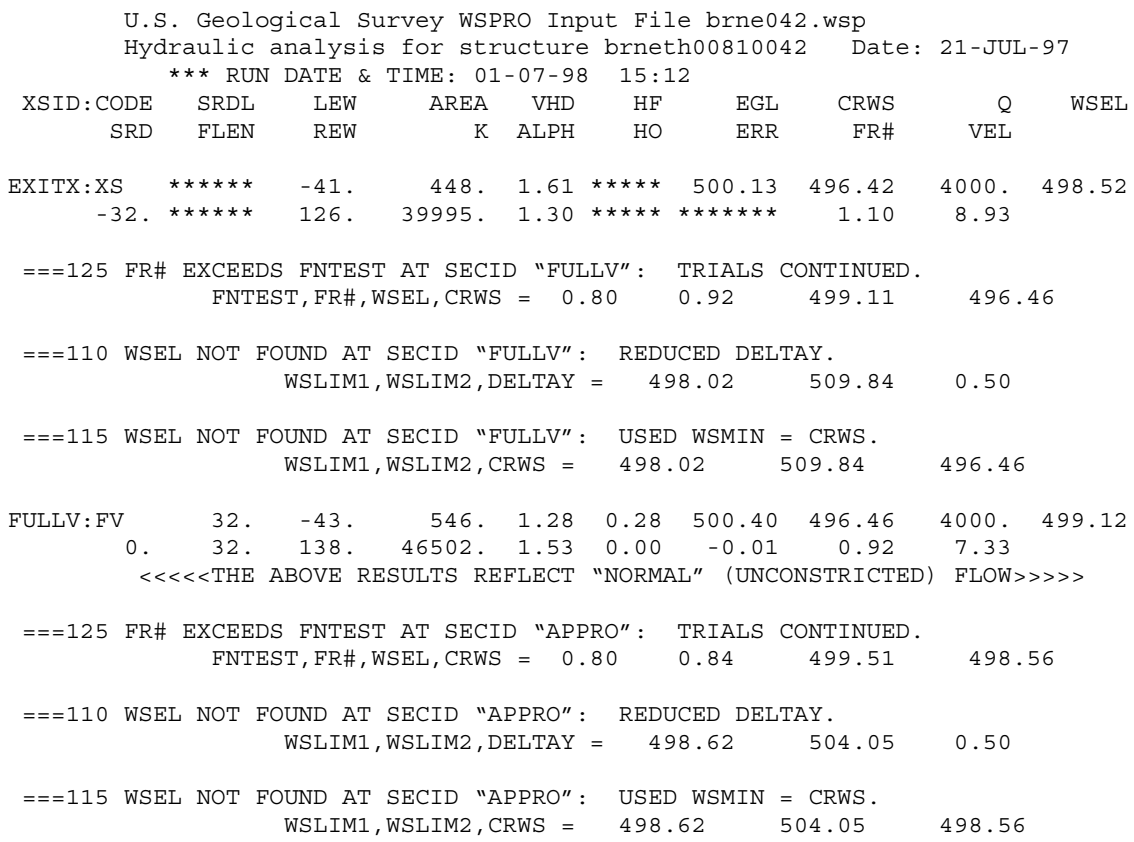


WSPRO OUTPUT FILE (continued)

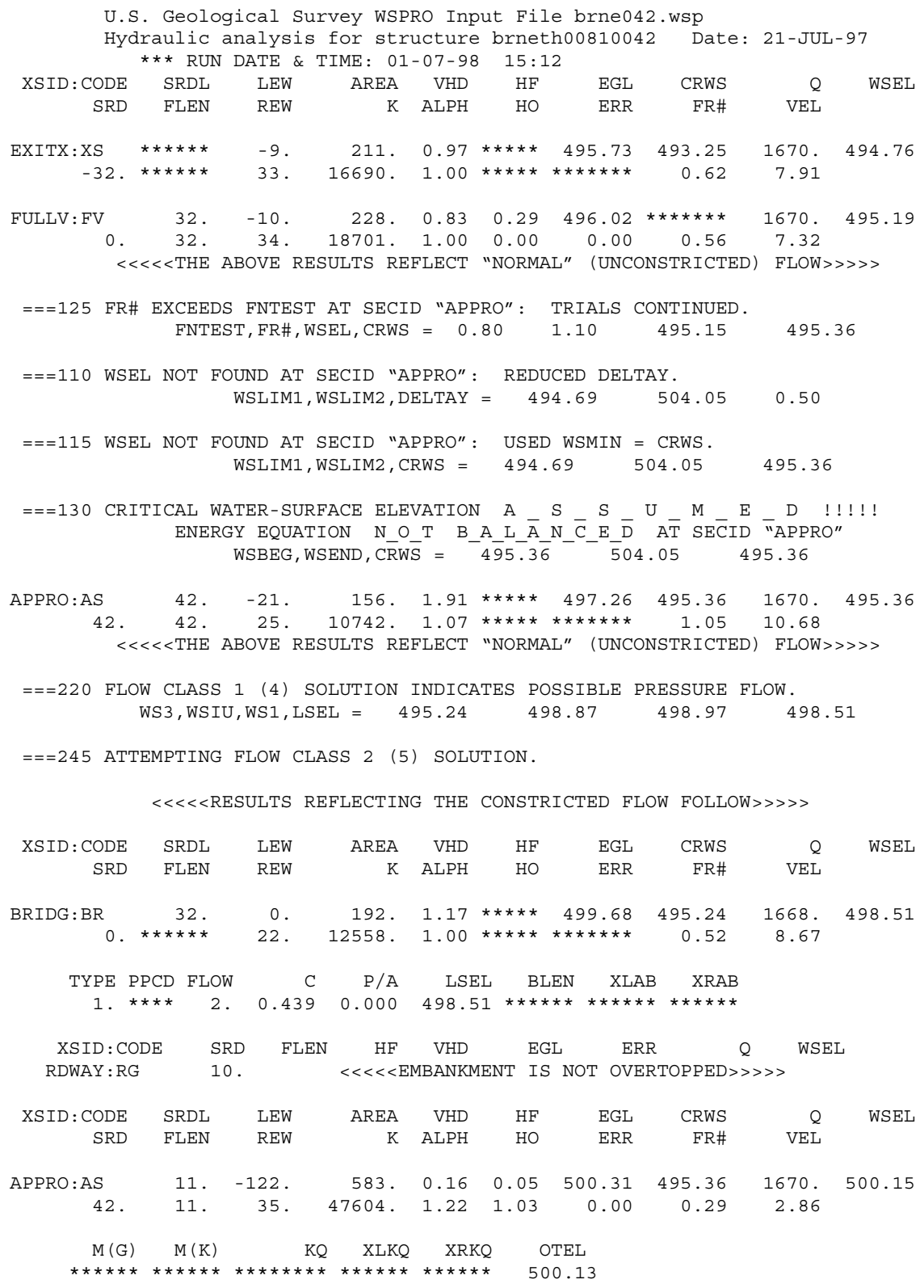

$<<<<<$ END OF BRIDGE COMPUTATIONS $>>>>>$

FIRST USER DEFINED TABLE.

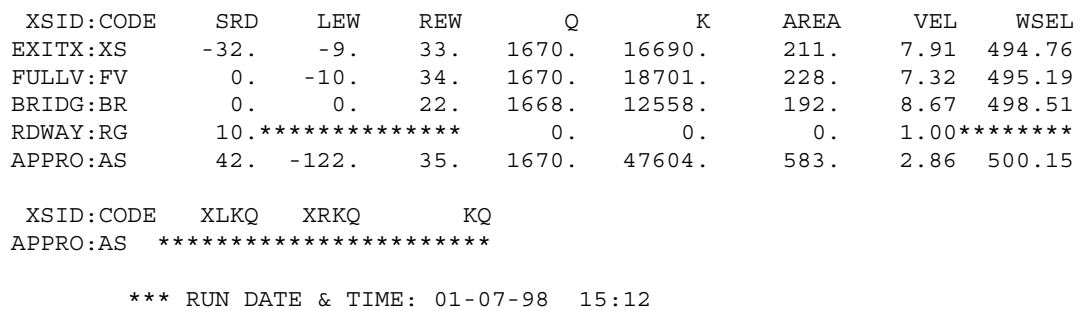

SECOND USER DEFINED TABLE.

\begin{tabular}{|c|c|c|c|c|c|c|c|c|c|}
\hline XSID: CODE & CRWS & FR\# & YMIN & YMAX & $\mathrm{HF}$ & HO & VHD & EGL & WSEL \\
\hline EXITX:XS & 493.25 & 0.62 & 488.08 & $509.81 *$ & $\star * \star * * *$ & $\star \star \star \star \star *$ & 0.97 & 495.73 & 494.76 \\
\hline FULLV : FV & 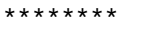 & 0.56 & 488.11 & 509.84 & 0.29 & 0.00 & 0.83 & 496.02 & 495.19 \\
\hline BRIDG : BR & 495.24 & 0.52 & 488.16 & $498.51 *$ & $\star * \star * \star * *$ & $\star \star \star * *$ & 1.17 & 499.68 & 498.51 \\
\hline RDWAY : RG & 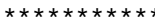 & $\star \star \star \star \star *$ & 500.14 & $504.10 *$ & $\star \star \star \star \star \star \star *$ & $\star \star \star * * *$ & 0.16 & 500.28 * & 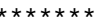 \\
\hline APPRO: AS & 495.36 & 0.29 & 488.31 & 504.05 & 0.05 & 1.03 & 0.16 & 500.31 & 500.15 \\
\hline
\end{tabular}




\section{APPENDIX C:}

\section{BED-MATERIAL PARTICLE-SIZE DISTRIBUTION}




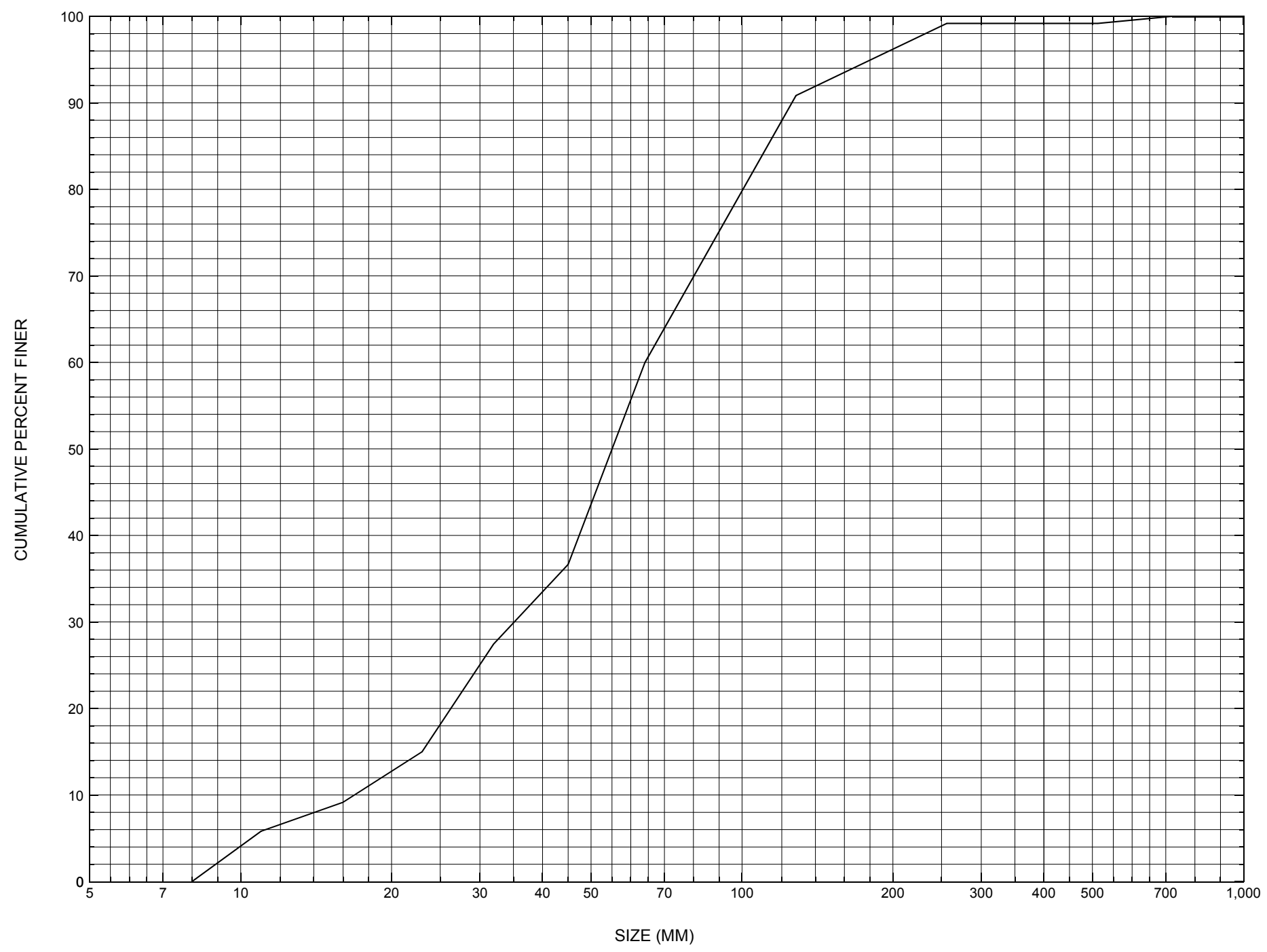

Appendix C. Bed material particle-size distribution for a pebble count in the channel approach of structure BRNETH00810042 in Barnet, Vermont. 


\section{APPENDIX D: \\ HISTORICAL DATA FORM}




\section{Structure Number BRNETH00810042}

\section{General Location Descriptive}

Data collected by (First Initial, Full last name) $\mathbf{E}$. BOEHMLER

Date $(M M / D D / Y Y) \_\mathbf{0 3} / \underline{23} / \underline{95}$

Highway District Number (I - 2; nn) $\mathbf{0 7}$

Town (FIPS place code; I - 4; nnnnn) $\mathbf{0 2 8 7 5}$

Waterway (I - 6) STEVENS RIVER

Route Number $\underline{\text { TH081 }}$

Topographic Map Barnet

Latitude (I - 16; nnnn.n) $\mathbf{4 4 1 8 7}$
County (FIPS county code; I - 3; nnn)

Mile marker (I - 11; nnn.nnn) $\mathbf{0 0 0 0 0 0}$

Road Name (I - 7): -

Vicinity (I - 9) 0.04 MI TO JCT W CL2 TH1

Hydrologic Unit Code: $\mathbf{0 1 0 8 0 1 0 3}$

Longitude (i - 17; nnnnn.n) $\mathbf{7 2 0 8 2}$

\section{Select Federal Inventory Codes}

FHWA Structure Number (I - 8) $\mathbf{1 0 0 3 0 1 0 0 4 2 0 3 0 1}$

Maintenance responsibility $(I-21 ; n n) \quad \mathbf{0 3} \quad$ Maximum span length $(I-48 ; n n n n) \underline{\mathbf{0 0 2 5}}$

Year built (I - 27; YYYY) 1926

Structure length (I - 49; nnnnnn) $\underline{\mathbf{0 0 0 0 2 9}}$

Average daily traffic, ADT (I - 29; nnnnnn) $\underline{000150}$ Deck Width (I- 52; nn.n) 193

Year of ADT (I-30; YY) $\mathbf{9 3}$

Channel \& Protection $(I-61 ; n) \underline{6}$

Opening skew to Roadway $(I-34 ; n n) \quad \mathbf{1 5}$

Waterway adequacy $(I-71 ; n)$

Operational status $(I-41 ; X) \underline{P}$

Underwater Inspection Frequency $(I-92 B ; X Y Y) \_\mathbf{N}$

Structure type (I- 43; nnn) $\mathbf{3 0 2}$

Year Reconstructed (I - 106) $\mathbf{0 0 0 0}$

Approach span structure type (I - 44; nnn) $\mathbf{0 0 0}$

Clear span (nnn.n ft)

Number of spans (I - 45; nnn) $\underline{\mathbf{0 0 1}}$

Vertical clearance from streambed (nnn.n ft) $\underline{\mathbf{0 0 7 . 8}}$

Number of approach spans (I - 46; nnnn) $\underline{\mathbf{0 0 0 0}}$ Waterway of full opening $\left(n n n . n \mathrm{ft}^{2}\right) \underline{\mathbf{1 8 5 . 9}}$

Comments:

The structural inspection report of 9/6/94 indicates the structure is a steel stringer type bridge with a concrete deck and asphalt roadway surface. The abutment walls and wingwalls are concrete. The right abutment and its wingwalls have widespread cracking and leaking reported through the cracks. Additionally, there are areas of spalling and displacement in the wall of about 4 inches. The left abutment and its wingwalls reportedly have some areas of cracking with leaking, and a large spall and break on the downstream wingwall. This abutment evidently is sealed or doweled into bedrock, which outcrops at the base of the wall. There is some stone fill along the front face of the left abutment. (Continued, page 34) 


\section{Bridge Hydrologic Data}

Is there hydrologic data available? $\underline{\mathbf{N}}$ if No, type ctrl-n $h \quad$ VTAOT Drainage area $\left(m i^{2}\right)$ : -

Terrain character:

Stream character \& type: -

Streambed material:

Discharge Data (cfs):

$$
\begin{aligned}
& Q_{2.33}- \\
& Q_{50}-
\end{aligned}
$$

Record flood date $(M M / D D / Y Y)$ :

Estimated Discharge (cfs): Ice conditions (Heavy, Moderate, Light) : -

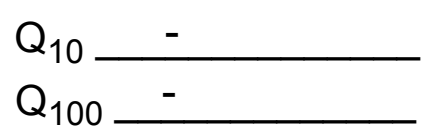

$$
\begin{aligned}
& Q_{25}- \\
& Q_{500}-
\end{aligned}
$$

Water surface elevation $(f t):-$

The stage increases to maximum highwater elevation (Rapidly, Not rapidly):

The stream response is (Flashy, Not flashy):

Describe any significant site conditions upstream or downstream that may influence the stream's stage: -

Watershed storage area (in percent): _ _ \%

The watershed storage area is: - (1-mainly at the headwaters; 2- uniformly distributed; 3-immediatly upstream oi the site)

Water Surface Elevation Estimates for Existing Structure:

\begin{tabular}{|l|l|l|l|l|l|}
\hline Peak discharge frequency & $Q_{2.33}$ & $Q_{10}$ & $Q_{25}$ & $Q_{50}$ & $Q_{100}$ \\
Water surface elevation (ft)) & - & - & - & - & - \\
Velocity (ft/sec) & - & - & - & - & - \\
\hline
\end{tabular}

Long term stream bed changes: -

Is the roadway overtopped below the $\mathrm{Q}_{100}$ ? (Yes, No, Unknown): $\mathbf{U} \quad$ Frequency: Relief Elevation (ft): Discharge over roadway at $Q_{100}\left(f^{3} / \mathrm{sec}\right)$ :

Are there other structures nearby? (Yes, No, Unknown): $\underline{\mathbf{U}}$ Upstream distance (miles): Town: If No or Unknown, type ctrl-n os Highway No. : Structure No. : Year Built:

Clear span (ft): Clear Height $(f t)$ : Full Waterway $\left(f^{2}\right)$ : 
Downstream distance (miles): Town: Year Built:

Highway No. : Structure No. : Structure Type:

Clear span $(f t):$ Clear Height (ft): Full Waterway $\left(f^{2}\right)$ :

Comments:

The channel bed consists of gravel, cobbles, and boulders under the bridge. The type of foundation recorded for this bridge is a spread footing. According to the report, even though the base of the left abutment is on bedrock, the footings are noted as not visible. Furthermore, undermining and settling are reported as not apparent. The report indicates some channel scour is evident just downstream. Debris accumulation and point bar development are noted as not evident.

\section{USGS Watershed Data}

Watershed Hydrographic Data

Drainage area $(D A) \stackrel{20.67}{\mathrm{mi}^{2}}$

Watershed storage (ST)

Bridge site elevation

Main channel length 886 6.13 $10 \%$ channel length elevation

Main channel slope (S) 136.81 $\mathrm{ft} / \mathrm{mi}$ $\%$ $\mathrm{mi}$

Lake/pond/swamp area

1.31 $\mathrm{mi}^{2}$

Headwater elevation 2369 $\mathrm{ft}$ $\mathrm{ft} \quad 85 \%$ channel length elevation $\mathrm{ft}$

Watershed Precipitation Data

Average site precipitation in Average headwater precipitation in

Maximum 2yr-24hr precipitation event $(124,2)$ in

Average seasonal snowfall (Sn) $\mathrm{ft}$ 


\section{Bridge Plan Data}

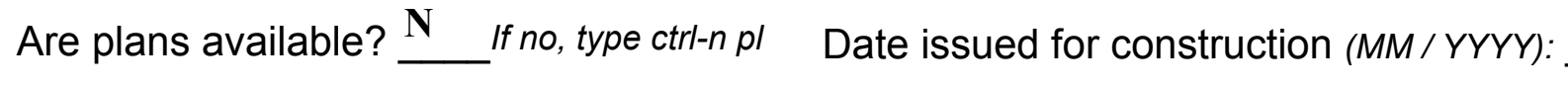

Project Number

Minimum channel bed elevation:

Low superstructure elevation: USLAB DSLAB USRAB DSRAB Benchmark location description:

NO BENCHMARK INFORMATION

Reference Point (MSL, Arbitrary, Other): Datum (NAD27, NAD83, Other):

Foundation Type: 4

If 1: Footing Thickness

If 2: Pile Type: (1-Wood; 2-Steel or metal; 3-Concrete)

If 3 : Footing bottom elevation:

Is boring information available? $\mathbf{N}$ If no, type ctrl-n bi Number of borings taken:

Foundation Material Type: $\mathbf{3}$ (1-regolith, 2-bedrock, 3-unknown)

Briefly describe material at foundation bottom elevation or around piles:

NO FOUNDATION MATERIAL INFORMATION

Comments:

NO PLANS 


\section{Cross-sectional Data}

Is cross-sectional data available? $\underline{\mathbf{Y}}$

If no, type ctrl-n xs

Source (FEMA, VTAOT, Other)? VTAOT

This cross section is the upstream face. The low chord elevation is from the survey log done for Comments: this report on $8 / 23 / 95$. The low chord to bed length data are from the sketch attached to a bridge inspection report dated 9/6/94. The sketch was done on 7/1/92.

\begin{tabular}{|c|c|c|c|c|c|c|c|c|c|c|c|}
\hline Station & 0 & 7.5 & 11.8 & 15.5 & 23.9 & - & - & - & - & - & - \\
\hline Feature & LAB & & & & RAB & - & - & - & - & - & - \\
\hline $\begin{array}{l}\text { Low chord } \\
\text { elevation }\end{array}$ & 498.5 & 498.5 & 498.5 & 498.5 & 498.5 & - & - & - & - & - & - \\
\hline $\begin{array}{l}\text { Bed } \\
\text { elevation }\end{array}$ & 491.2 & 489.6 & 488.1 & 489.5 & 491.4 & - & - & - & - & - & - \\
\hline $\begin{array}{l}\text { Low chord } \\
\text { to bed }\end{array}$ & 7.3 & 8.9 & 10.4 & 9.0 & 7.1 & - & - & - & - & - & - \\
\hline Station & - & - & - & - & - & - & - & - & - & - & - \\
\hline Feature & - & - & - & - & - & - & - & - & - & - & - \\
\hline $\begin{array}{l}\text { Low chord } \\
\text { elevation }\end{array}$ & - & - & - & - & - & - & - & - & - & - & - \\
\hline $\begin{array}{l}\text { Bed } \\
\text { elevation }\end{array}$ & - & - & - & - & - & - & - & - & - & - & - \\
\hline $\begin{array}{l}\text { Low chord } \\
\text { to bed }\end{array}$ & - & - & - & - & - & - & - & - & - & - & - \\
\hline
\end{tabular}

Source (FEMA, VTAOT, Other)?

Comments:

\begin{tabular}{|c|c|c|c|c|c|c|c|c|c|c|c|}
\hline Station & - & - & - & - & - & - & - & - & - & - & - \\
\hline Feature & - & - & - & - & - & - & - & - & - & - & - \\
\hline $\begin{array}{l}\text { Low chord } \\
\text { elevation }\end{array}$ & - & - & - & - & - & - & - & - & - & - & - \\
\hline $\begin{array}{l}\text { Bed } \\
\text { elevation }\end{array}$ & - & - & - & - & - & - & - & - & - & - & - \\
\hline $\begin{array}{l}\text { Low chord } \\
\text { to bed }\end{array}$ & - & - & - & - & - & - & - & - & - & - & - \\
\hline Station & - & - & - & - & - & - & - & - & - & - & - \\
\hline Feature & - & - & - & - & - & - & - & - & - & - & - \\
\hline $\begin{array}{l}\text { Low chord } \\
\text { elevation }\end{array}$ & - & - & - & - & - & - & - & - & - & - & - \\
\hline $\begin{array}{l}\text { Bed } \\
\text { elevation }\end{array}$ & - & - & - & - & - & - & - & - & - & - & - \\
\hline $\begin{array}{l}\text { Low chord } \\
\text { to bed }\end{array}$ & - & - & - & - & - & - & - & - & - & - & - \\
\hline
\end{tabular}




\section{APPENDIX E: \\ LEVEL I DATA FORM}


U. S. Geological Survey

Bridge Field Data Collection and Processing Form

Qa/Qc Check by: $\mathbf{R B}$ Date: $2 / 26 / 96$

\section{Structure Number}

BRNETH00810042

Computerized by: $\underline{\mathbf{R B}}$ Date: $2 / 26 / 96$

Reviewd by: MS Date: $\underline{1 / 12 / 98}$

\section{A. General Location Descriptive}

1. Data collected by (First Initial, Full last name) E. BOEHMLER

Date $(M M / D D / Y Y) \underline{8}$

2. Highway District Number 07

County CALEDONIA (005)

Waterway (I - 6) STEVENS RIVER

Route Number TH081

3. Descriptive comments:

This bridge is located about 200 feet east of the intersection of Town Highway 81 with Town Highway 1.
Mile marker $\mathbf{0 0 0 0}$

Town BARNET (02875)

Road Name -

Hydrologic Unit Code: $\mathbf{0 1 0 8 0 1 0 3}$

\section{B. Bridge Deck Observations}
4. Surface cover... LBUS 4
RBUS 5
LBDS 4
RBDS 5
Overall 4

(2b us, ds,lb,rb: 1- Urban; 2- Suburban; 3- Row crops; 4- Pasture; 5- Shrub- and brushland; 6- Forest; 7- Wetland)
5. Ambient water surface... US 1
UB 1
DS 1
(1- pool; 2- riffle)

6. Bridge structure type 1 (1- single span; 2- multiple span; 3- single arch; 4- multiple arch; 5-cylindrical culvert; 6- box culvert; or 7- other)
7. Bridge length 29
(feet)
Span length $\mathbf{2 5}$
(feet)
Bridge width 19.3 (feet)

\section{Road approach to bridge:}
8. LB 0
RB 2
( 0 even, 1- lower, 2- higher)
9. LB RB 1
(1- Paved, 2- Not paved)

10. Embankment slope (run / rise in feet / foot)

US left

US right

\begin{tabular}{|c|c|c|c|}
\hline \multicolumn{2}{|c|}{ Protection } & \multirow{2}{*}{ 13.Erosion } & 14.Severity \\
\hline 11.Type & 12.Cond. & $\mathbf{0}$ & $\mathbf{0}$ \\
\hline $\mathbf{0}$ & - & $\mathbf{0}$ & $\mathbf{0}$ \\
\hline $\mathbf{0}$ & - & $\mathbf{0}$ & $\underline{\mathbf{0}}$ \\
\hline $\mathbf{0}$ & - & $\mathbf{1}$ \\
\hline $\mathbf{0}$ & - & $\mathbf{0}$ & $\mathbf{0}$ \\
\hline
\end{tabular}

Bank protection types: 0- none; 1- < 12 inches;

2- < 36 inches; 3- < 48 inches;

4- < 60 inches; 5- wall / artificial levee

Bank protection conditions: 1- good; 2- slumped;

3- eroded; 4- failed

Erosion: 0 - none; 1- channel erosion; 2 -

road wash; 3- both; 4- other

Erosion Severity: 0 - none; 1- slight; 2- moderate; 3- severe

\section{Channel approach to bridge (BF):}

15. Angle of approach: $\mathbf{0}$

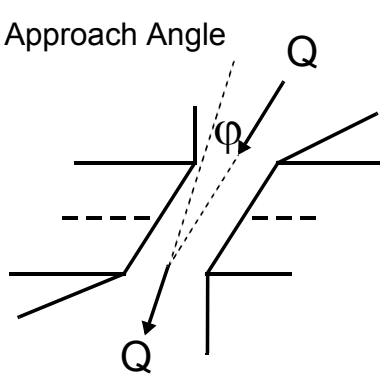

17. Channel impact zone 1:

Where? LB $(L B, R B)$

Range? 25

Channel impact zone 2:

Where? RB $(L B, R B)$

Range? $\underline{35}$ feet DS

Impact Severity: 0- none to very slight; 1- Slight; 2- Moderate; 3- Severe
16. Bridge skew: 15 Bridge Skew Angle

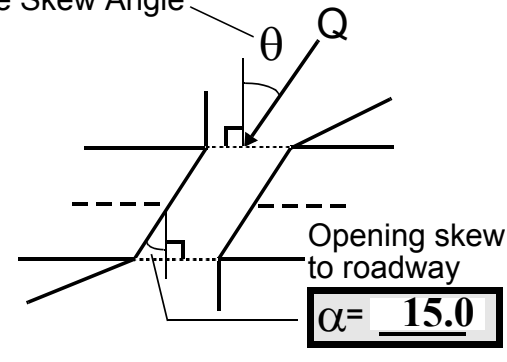

\section{Exist? $\mathbf{Y}(Y$ or $N)$}

Severity 1

$U B, D S)$ to $\mathbf{5}$ feet $\underline{\mathbf{U S}}$

Exist? $\mathbf{Y}(Y$ or $N)$

Severity 1

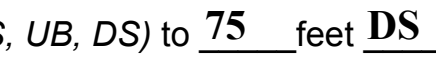


18. Bridge Type: 1a

1a- Vertical abutments with wingwalls

1 b- Vertical abutments without wingwalls

2- Vertical abutments and wingwalls, sloping embankment Wingwalls parallel to abut. face

3- Spill through abutments

4- Sloping embankment, vertical wingwalls and abutments

Wingwall angle less than $90^{\circ}$.

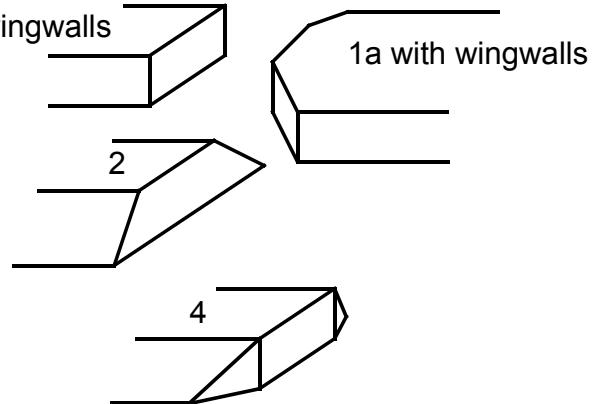

19. Bridge Deck Comments (surface cover variations, measured bridge and span lengths, bridge type variations, approach overflow width, etc.)

4. Surface cover on the US left bank consists of a lawn around a church. A bit DS and behind the church is a shed. On the DS left bank there is a lawn and a house. The US and DS right banks have weeds, shrubs, and small trees. TH81 bisects the US right bank coverage. Beyond 2 bridge lengths on the US right bank is forest. The DS right bank has older trees only along the immediate side of the channel. Overflow will occur over the left bank road approach before topping the bridge deck.

7. These values are from VTAOT files. The measured bridge length, span length, and bridge width are $27 \mathrm{ft}$, $25 \mathrm{ft}$, and $19.3 \mathrm{ft}$, respectively.

\section{Upstream Channel Assessment}

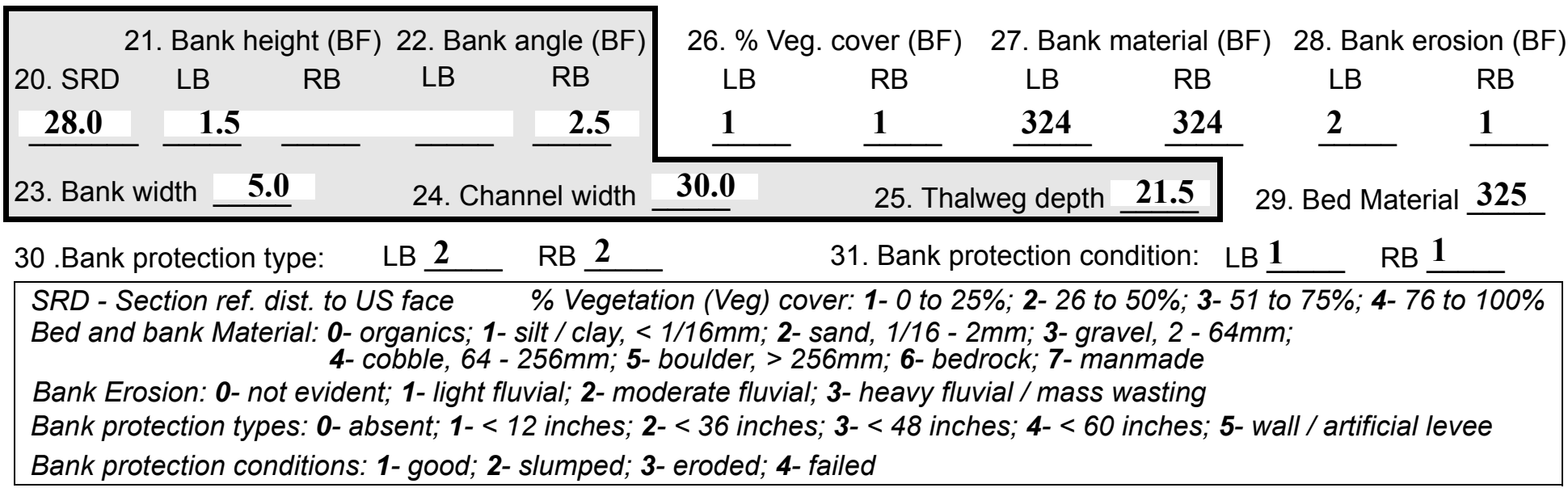

32. Comments (bank material variation, minor inflows, protection extent, etc.):

The right bank protection extends from 65 feet US to the US face of the bridge. The left bank protection extends from 20 feet US to the US bridge face. The left bank side is eroding moderately and is cut as indicated. The cutting process is not due to a meander bend but due to the US channel constriction by stone fill on the right bank. The left bank side is freshly eroded. 
33.Point/Side bar present? $\mathbf{N}(Y$ or $N$. if $N$ type ctrl-n pb)34. Mid-bar distance: -

35. Mid-bar width: -

36. Point bar extent: feet (US, UB) to feet (US, UB, DS) positioned $\%$ LB to $\%$ RB

37. Material: -

38. Point or side bar comments (Circle Point or Side; Note additional bars, material variation, status, etc.):

NO POINT BARS

39. Is a cut-bank present? $\underline{\mathbf{Y}}$ ( $Y$ or if $N$ type $c t r-n c b)$ 40. Where? LB (LB or RB)

41. Mid-bank distance: $\mathbf{5 5}$

42. Cut bank extent: 70

\section{(US, $U$, 1025} feet $\underline{\text { US }}$ (US, UB, DS)

43. Bank damage: 3

(1- eroded and/or creep; 2- slip failure; 3- block failure)

44. Cut bank comments (eg. additional cut banks, protection condition, etc.):

Cutting is due to channel widening.

\section{Is channel scour present? $\mathbf{Y}$ ( $Y$ or if $N$ type ctrl-n cs)}

47. Scour dimensions: Length $\mathbf{1 8}$ Width 6 Depth : 1

46. Mid-scour distance: $\underline{43}$

48. Scour comments (eg. additional scour areas, local scouring process, etc.):

Scouring of bed is occurring US where stone fill on the right bank begins to influence flow by constricting the channel. Currently the deepest pools in the channel elsewhere are no more than 0.5 feet deep.

\section{Are there major confluences? $\mathbf{N}$}

51. Confluence 1: Distance Confluence 2: Distance 52. Enters on Enters on 54. Confluence comments (eg. confluence name):

\section{NO MAJOR CONFLUENCES}

50. How many? -

53. Type -
Type
( $L B$ or $R B)$ (LB or $R B)$
Position $\underline{40} \%$ LB to $\underline{100} \% R B$
etc.):
re begins to influence flow by
ro more than 0.5 feet deep.

\section{Under Bridge Channel Assessment}

55. Channel restraint (BF)? LB 2

\begin{tabular}{|ccccc}
\hline \multicolumn{2}{|c}{ 56. Height (BF) } & \multicolumn{3}{c}{57 Angle (BF) } \\
LB & RB & LB & RB \\
$\mathbf{2 . 0}$ & & & $\mathbf{1 . 0}$ & \\
\hline
\end{tabular}

58. Bank width (BF) -

59. Channel width (1- natural bank; 2- abutment; 3- artificial levee)

Bed and bank Material: 0- organics; 1- silt / clay, < 1/16mm; 2- sand, 1/16 - 2mm; 3- gravel, 2 - 64mm; 4- cobble, 64 - 256mm; 5- boulder, > 256mm; 6- bedrock; 7- manmade

Bank Erosion: 0- not evident; 1- light fluvial; 2- moderate fluvial; 3- heavy fluvial / mass wasting

64. Comments (bank material variation, minor inflows, protection extent, etc.):

352

The channel under the bridge is constricted by bedrock on the DS half of the right side where the rock juts out 10 feet from the right abutment wall and is about 4.5 feet higher than the adjacent stream bed near mid-channel. The channel is further constricted by stone fill on the left abutment, which also sits 4.5 feet high from the lowest channel spot adjacent to the stone fill, and up to 5 feet toward the channel from the left abutment wall. 
65. Debris and Ice Is there debris accumulation?

$(Y$ or $N)$ 66. Where? $\mathbf{N}$

(1- Upstream; 2- At bridge; 3- Both)

67. Debris Potential ( 1- Low; 2- Moderate; 3- High)

68. Capture Efficiency 2

(1-Low; 2- Moderate; 3- High)

69. Is there evidence of ice build-up? 2

Ice Blockage Potential $\mathbf{N}$

(1- Low; 2- Moderate; 3- High)

70. Debris and Ice Comments:

2

The banks are fairly stable but have a lot of trees, shrubs, and brush on them. The channel does not bend much under the bridge but debris may get lodged on bedrock or stone fill.

\begin{tabular}{|l|c|c|c|c|c|c|c|c|}
\hline Abutments & $\begin{array}{c}71 . \text { Attack } \\
\angle \text { (BF) }\end{array}$ & $\begin{array}{c}72 \text {. Slope } \angle \\
\text { (Qmax) }\end{array}$ & $\begin{array}{c}\text { 73. Toe } \\
\text { loc. (BF) }\end{array}$ & $\begin{array}{c}\text { 74. Scour } \\
\text { Condition }\end{array}$ & $\begin{array}{c}75 . \text { Scour } \\
\text { depth }\end{array}$ & $\begin{array}{c}\text { 76. Exposure } \\
\text { depth }\end{array}$ & 77. Material & 78. Length \\
\hline LABUT & & $\mathbf{0}$ & $\mathbf{9 0}$ & $\mathbf{2}$ & $\mathbf{0}$ & $\mathbf{0}$ & $\mathbf{0}$ & $\mathbf{9 0 . 0}$ \\
\hline RABUT & $\mathbf{1}$ & - & $\mathbf{9 0}$ & & & $\mathbf{2}$ & $\mathbf{0}$ & $\mathbf{2 1 . 5}$ \\
\hline
\end{tabular}

Pushed: $L B$ or RB

Toe Location (Loc.): 0- even, 1- set back, 2- protrudes

Scour cond.: 0- not evident; 1- evident (comment); 2- footing exposed; 3-undermined footing; 4- piling exposed; 5- settled; 6- failed

Materials: 1- Concrete; 2- Stone masonry or drywall; 3- steel or metal; 4- wood

79. Abutment comments (eg. undermined penetration, unusual scour processes, debris, etc.):

0

0

1

80. Wingwalls:

Exist? Material? Scour Scour Exposure $\stackrel{81 .}{\text { Angle? Length? }}$ Condition? depth? depth?

USLWW:

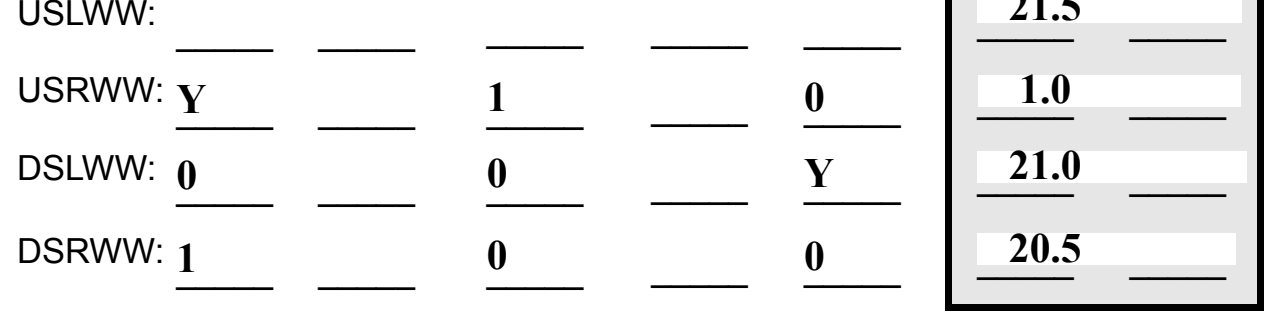

Wingwall materials: 1- Concrete; 2- Stone masonry or drywall; 3- steel or metal; 4- wood

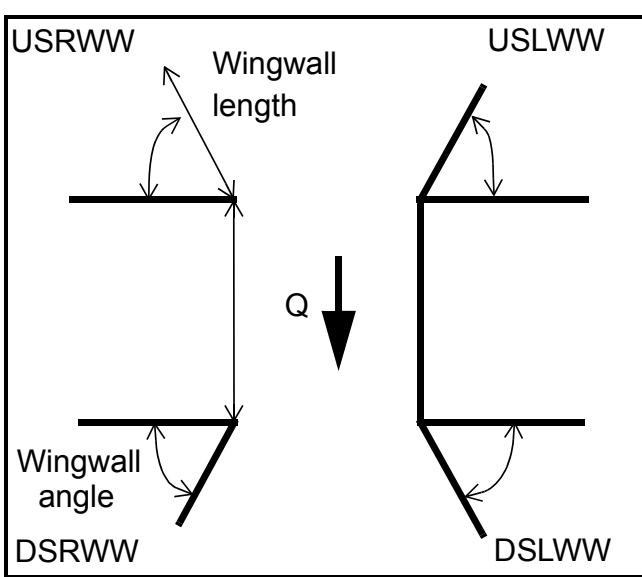

82. Bank / Bridge Protection:

\begin{tabular}{|l|l|l|l|l|l|l|l|c|}
\hline Location & USLWW & USRWW & LABUT & RABUT & LB & RB & DSLWW & DSRWW \\
\hline Type & $\mathbf{0}$ & $\mathbf{0}$ & $\mathbf{Y}$ & $\mathbf{0}$ & $\mathbf{1}$ & $\mathbf{1}$ & $\mathbf{1}$ & $\mathbf{1}$ \\
\hline Condition & $\mathbf{Y}$ & $\mathbf{0}$ & $\mathbf{1}$ & $\mathbf{0}$ & $\mathbf{1}$ & $\mathbf{1}$ & $\mathbf{1}$ & $\mathbf{1}$ \\
\hline Extent & $\mathbf{1}$ & $\mathbf{0}$ & $\mathbf{0}$ & $\mathbf{2}$ & $\mathbf{2}$ & $\mathbf{3}$ & $\mathbf{2}$ & - \\
\hline
\end{tabular}

Bank / Bridge protection types: 0- absent; 1- < 12 inches; 2- < 36 inches; 3- < 48 inches; 4- < 60 inches; 
83. Wingwall and protection comments (eg. undermined penetration, unusual scour processes, etc.):

-
-
-
-
-
2
1
1
1
1
1

Piers:

84. Are there piers? Th (Y or if N type ctrl-n pr)

\begin{tabular}{|l|l|l|l|l|l|l|l|}
\hline \multirow{2}{*}{$\begin{array}{l}85 . \\
\text { Pier no. }\end{array}$} & \multicolumn{3}{|c|}{ width (w) feet } & \multicolumn{3}{c|}{ elevation (e) feet } \\
\cline { 2 - 8 } & w1 & w2 & w3 & e@w1 & e@w2 & e@w3 \\
\hline Pier 1 & & & & $\mathbf{7 5 . 0}$ & $\mathbf{1 1 . 5}$ & $\mathbf{5 5 . 0}$ \\
\hline Pier 2 & & & & $\mathbf{1 2 . 0}$ & $\mathbf{4 0 . 0}$ & $\mathbf{1 3 . 5}$ \\
\hline Pier 3 & & & - & $\mathbf{5 5 . 0}$ & $\mathbf{1 4 . 5}$ & - \\
\hline Pier 4 & - & - & - & - & - & - \\
\hline
\end{tabular}

\begin{tabular}{|l|l|l|l|l|}
\hline Level 1 Pier Descr. & \multicolumn{1}{|c|}{1} & \multicolumn{1}{|c|}{2} & \multicolumn{1}{|c|}{3} & \multicolumn{1}{|c|}{} \\
\hline 86. Location (BF) & e pro- & US & sur- & is cov- \\
\hline 87. Type & tec- & half & face. & ered \\
\hline 88. Material & tion & wher & The & by \\
\hline 89. Shape & on & e the & pro- & sand \\
\hline 90. Inclined? & the & bed- & tec- & and \\
\hline 91. Attack $\angle$ (BF) & right & rock & tion & fine \\
\hline 92. Pushed & abut & is & on & grav \\
\hline 93. Length (feet) & - & - & - & - \\
\hline 94. \# of piles & ment & not & the & el \\
\hline 95. Cross-members & is & visi- & DS & from \\
\hline 96. Scour Condition & only & ble & right & the \\
\hline 97. Scour depth & on & on & wing & chan \\
\hline 98. Exposure depth & the & the & wall & nel. \\
\hline
\end{tabular}

LFP, LTB, LB, MCL, MCM, MCR, RB, RTB, RFP

1- Solid pier, 2- column, 3- bent

1-Wood; 2- concrete; 3- metal; 4- stone

1- Round; 2- Square; 3- Pointed

Y-yes; $N-$ no

$L B$ or $R B$

0- none; 1- laterals; 2- diagonals; 3- both

0- not evident; 1- evident (comment);

2- footing exposed; 3- piling exposed;

4- undermined footing; 5 - settled; 6 - failed 
99. Pier comments (eg. undermined penetration, protection and protection extent, unusual scour processes, etc.):

The US right wingwall protection is visible more toward the stream edge but back by the wall is covered with sand and fine gravel like the DS right wingwall.

$\mathbf{N}$

100.

\section{E. Downstream Channel Assessment}

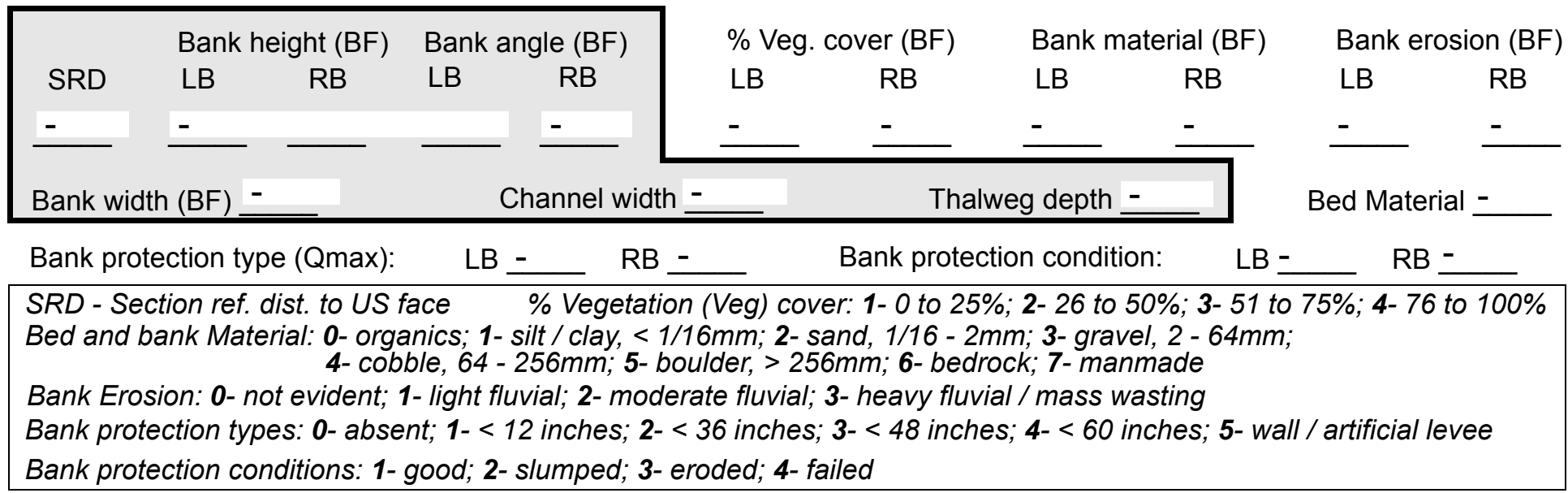

Comments (eg. bank material variation, minor inflows, protection extent, etc.):

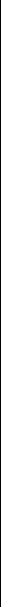

\section{Is a drop structure present? _- (Y or N, if $N$ type ctrl-n ds) 102. Distance: _ _ feet}
103. Drop: - feet
104. Structure material:
(1- steel sheet pile; 2- wood pile; 3- concrete; 4- other)

105. Drop structure comments (eg. downstream scour depth): 
106. Point/Side bar present? (Y or $N$. if $N$ type ctrl-n pb)Mid-bar distance:

Mid-bar width: -

Point bar extent: feet -

(US, UB, DS) to feet (US, UB, DS) positioned $\%$ LB to $\% \mathrm{RB}$ Material:

Point or side bar comments (Circle Point or Side; note additional bars, material variation, status, etc.):

S a cut-bank present? $\mathbf{N}$ (Y or if $N$ type ctrl-n cb) Where? $\underline{\mathbf{O}}$ (LB or RB) Mid-bank distance: PIE Cut bank extent: $\underline{\mathbf{R S}}$ feet ___ (US, UB, DS) to feet ___ (US, UB, DS)

Bank damage: (1- eroded and/or creep; 2- slip failure; 3- block failure)

Cut bank comments (eg. additional cut banks, protection condition, etc.):

Is channel scour present? (Y or if $N$ type ctrl-n cs) Scour dimensions: Length 2 Width 324 Depth: 342 Scour comments (eg. additional scour areas, local scouring process, etc.): 342

0

$\mathbf{0}$

Are there major confluences? Confluence 1: Distance e is Confluence 2: Distance proEnters on nat- (LB or RB) Enters on tec- (LB or RB) Mid-scour distance: 1 Positioned $\underline{1}$ \%LB to $\underline{1}$ \%RB Confluence comments (eg. confluence name):

on the right bank from 30 feet DS to about 65 feet DS. There are a few scattered boulders in the channel as well.

\section{F. Geomorphic Channel Assessment}

107. Stage of reach evolution

1- Constructed

2- Stable

3- Aggraded

4- Degraded

5- Laterally unstable

6- Vertically and laterally unstable 
108. Evolution comments (Channel evolution not considering bridge effects; See HEC-20, Figure 1 for geomorphic descriptors): 


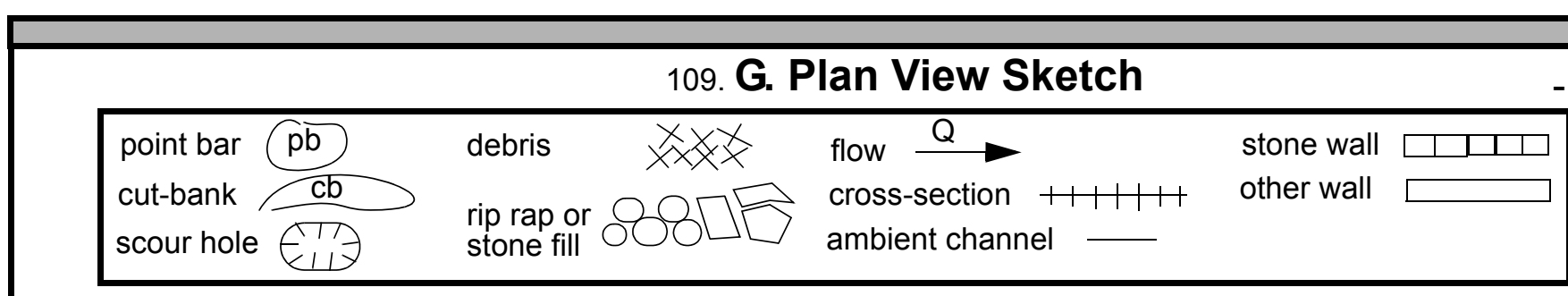


APPENDIX F:

SCOUR COMPUTATIONS 
SCOUR COMPUTATIONS

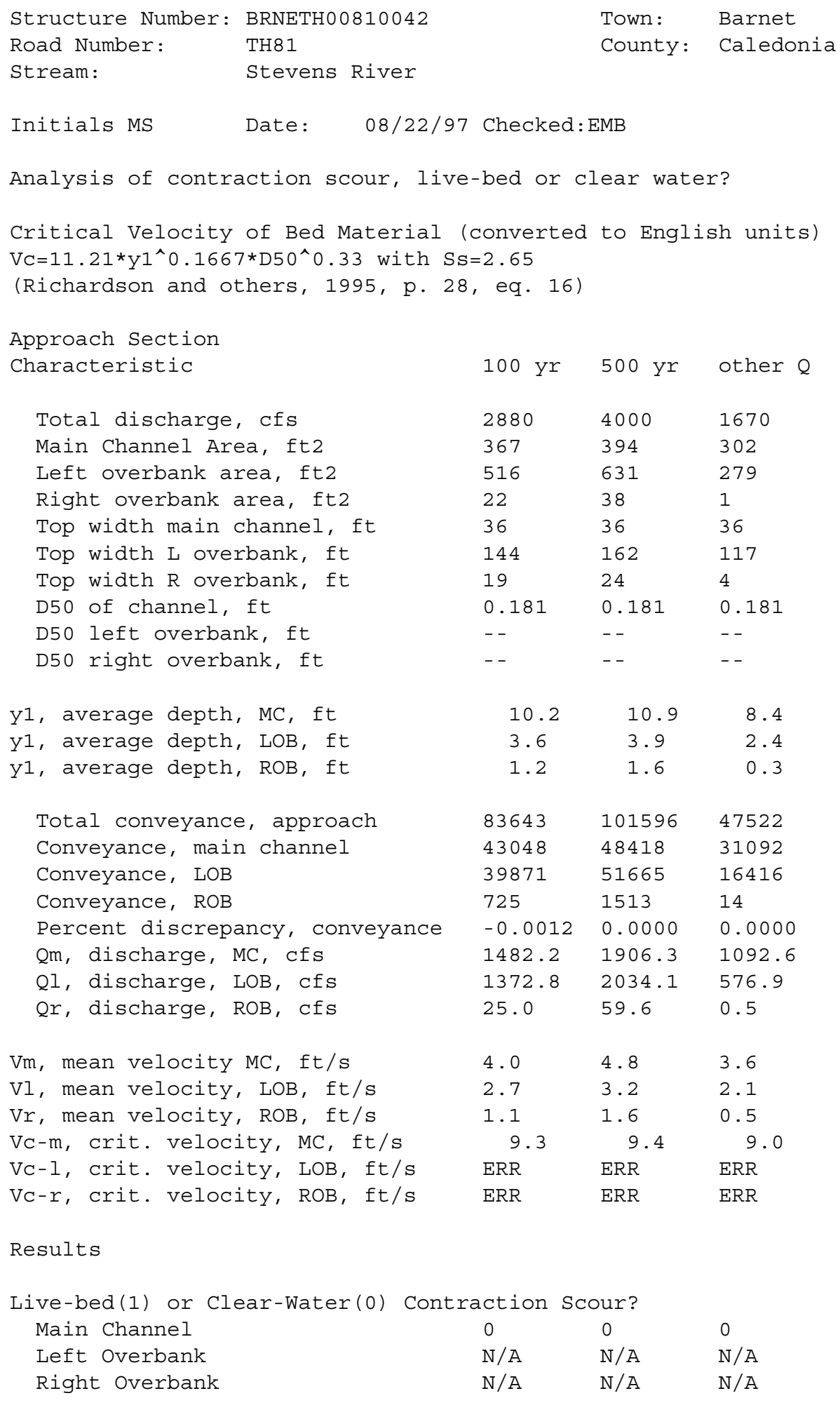




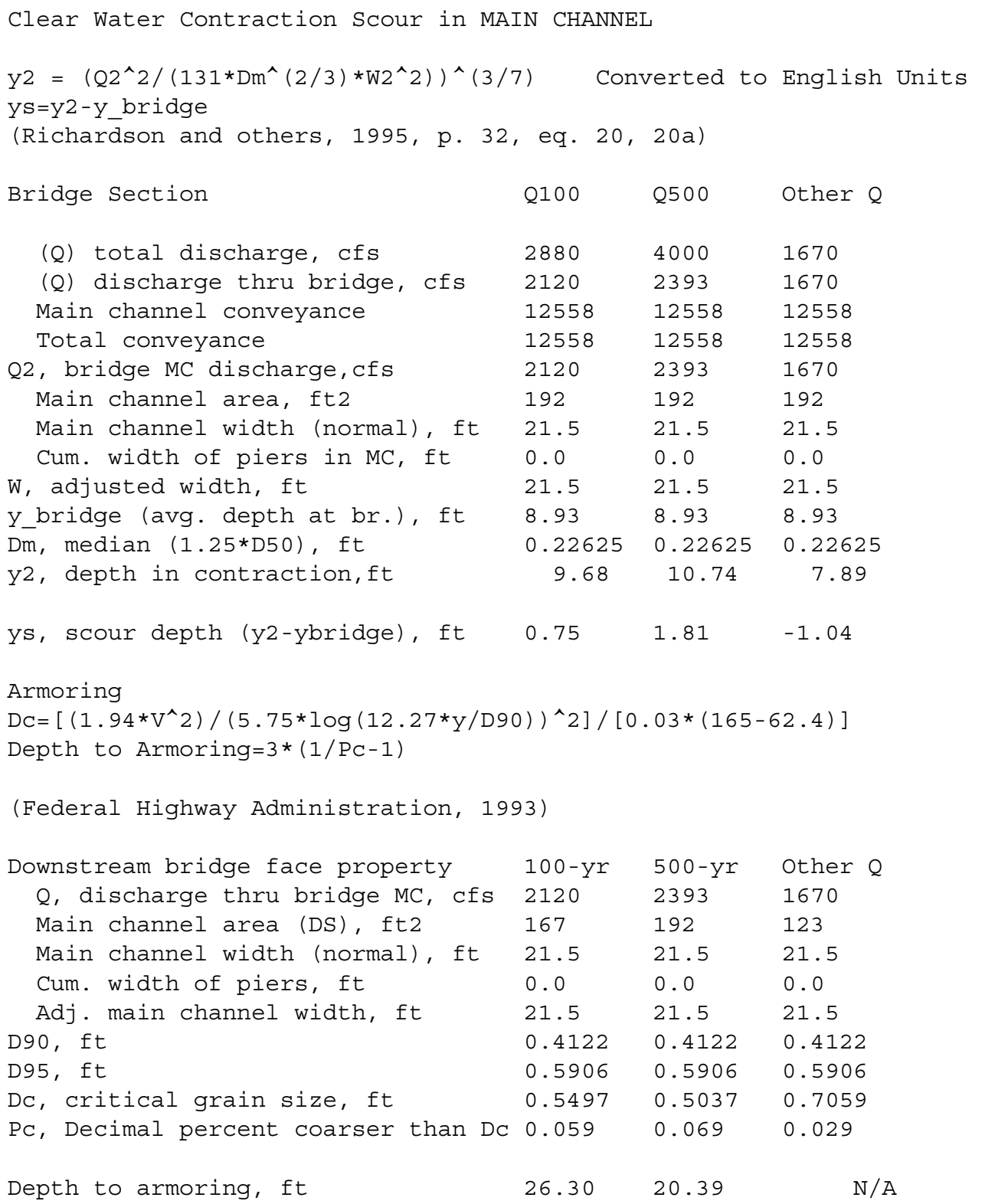




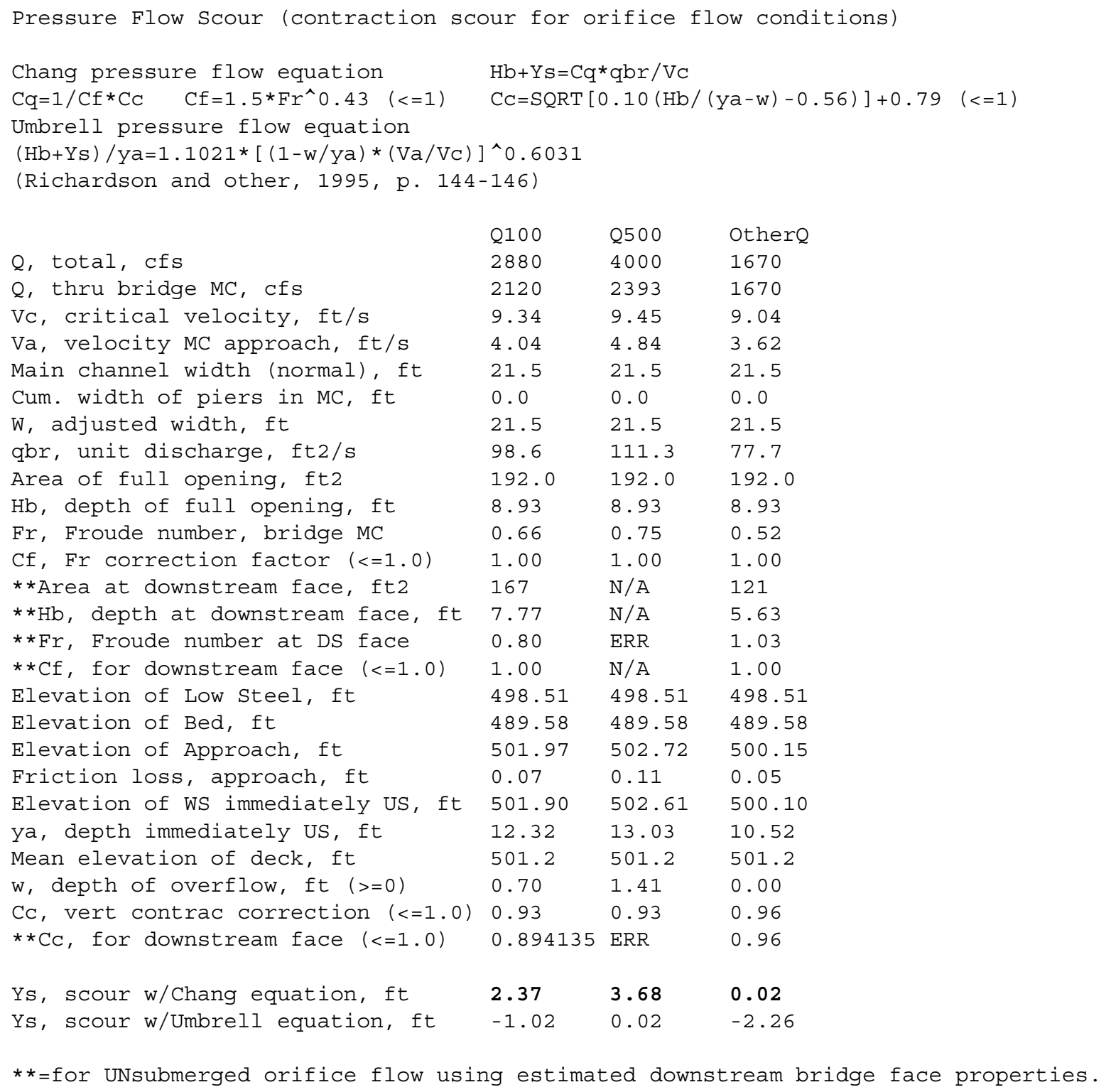




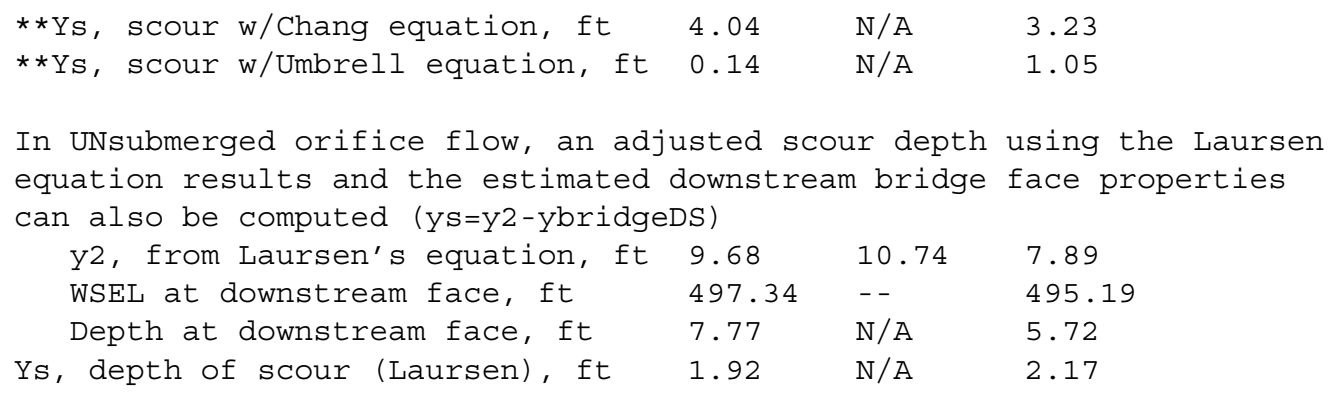

Abutment Scour

Froehlich's Abutment Scour

$\mathrm{Ys} / \mathrm{Y} 1=2.27 * \mathrm{~K} 1 * \mathrm{~K} 2 *\left(\mathrm{a}^{\prime} / \mathrm{Y} 1\right)^{\wedge} 0.43 * \mathrm{Fr} 1 \wedge 0.61+1$

(Richardson and others, 1995, p. 48, eq. 28)

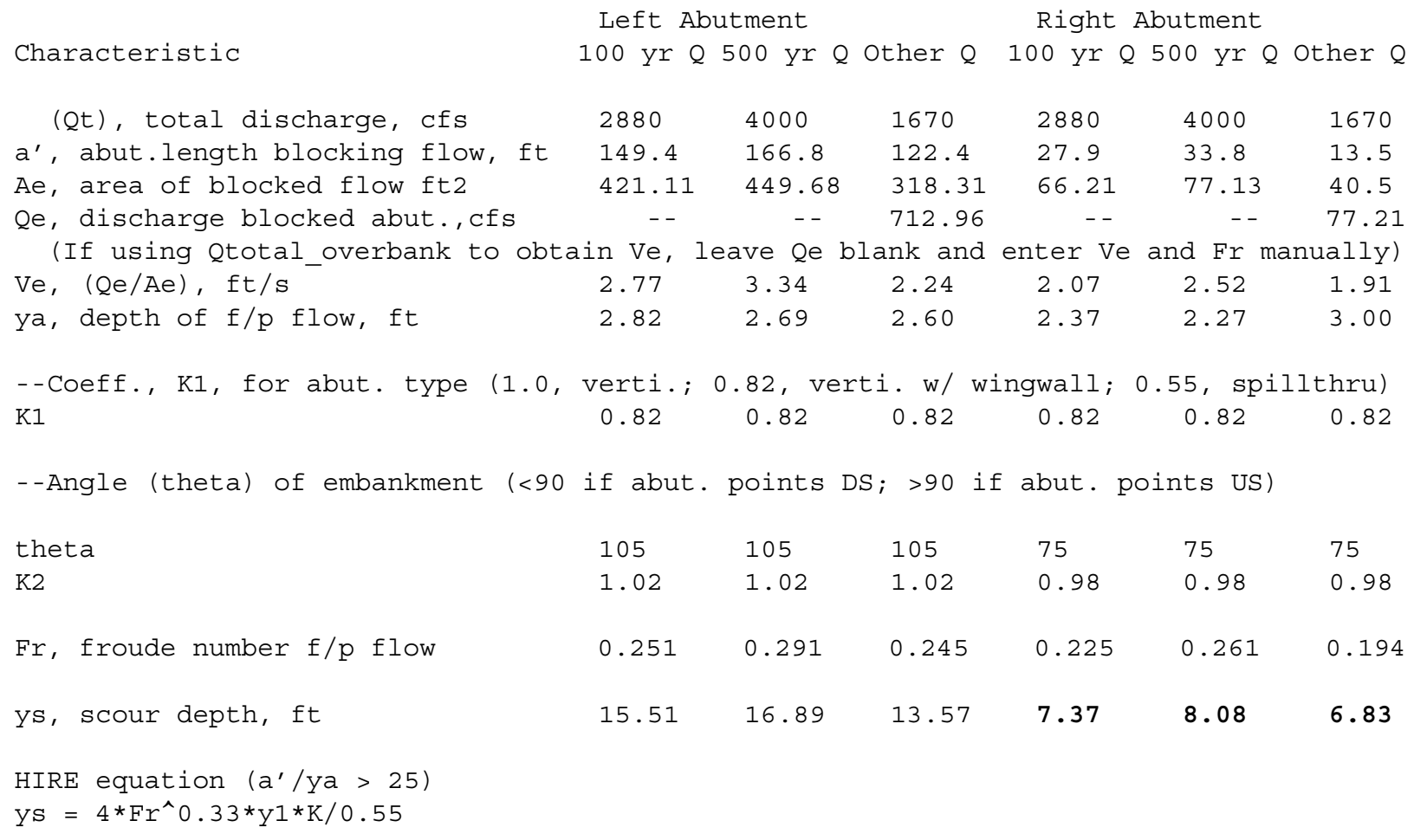


(Richardson and others, 1995, p. 49, eq. 29)

\begin{tabular}{|c|c|c|c|c|c|c|}
\hline$a^{\prime}$ (abut length blocked, ft) & 149.4 & 166.8 & 122.4 & 27.9 & 33.8 & 13.5 \\
\hline y1 (depth f/p flow, ft) & 2.82 & 2.69 & 2.60 & 2.37 & 2.27 & 3.00 \\
\hline$a^{\prime} / y^{1}$ & 53.03 & 61.95 & 47.07 & 11.79 & 14.87 & 4.50 \\
\hline Skew correction (p. 49, fig. 16) & 1.03 & 1.03 & 1.03 & 0.95 & 0.95 & 0.95 \\
\hline Froude no. f/p flow & 0.25 & 0.29 & 0.24 & 0.23 & 0.26 & 0.19 \\
\hline \multirow{3}{*}{$\begin{array}{l}\text { Ys w/ corr. factor } \mathrm{Kl} / 0.55 \\
\text { vertical } \\
\text { vertical w/ ww's } \\
\text { spill-through }\end{array}$} & 13.41 & 13.46 & 12.28 & ERR & ERR & ERR \\
\hline & 11.00 & 11.04 & 10.07 & ERR & ERR & ERR \\
\hline & 7.38 & 7.40 & 6.75 & ERR & ERR & ERR \\
\hline \multicolumn{7}{|l|}{ Abutment riprap sizing } \\
\hline \multirow{3}{*}{\multicolumn{7}{|c|}{$\begin{array}{l}\text { Isbash Relationship } \\
\mathrm{D} 50=\mathrm{Y}^{\star} \mathrm{K} * \mathrm{Fr} r^{\wedge} 2 /(\mathrm{Ss}-1) \text { and } \mathrm{D} 50=\mathrm{Y}^{*} \mathrm{~K}^{*}\left(\mathrm{Fr} r^{\wedge} 2\right)^{\wedge} 0.14 /(\mathrm{Ss}-1) \\
\text { (Richardson and others, 1995, p112, eq. 81,82) }\end{array}$}} \\
\hline & & & & & & \\
\hline & & & & & & \\
\hline Characteristic & Q100 & Q500 & Other $Q$ & Q100 & Q500 & Other $Q$ \\
\hline \multirow{2}{*}{$\begin{array}{l}\text { Fr, Froude Number } \\
\text { y, depth of flow in bridge, ft }\end{array}$} & 0.66 & 0.75 & 0.52 & 0.66 & 0.75 & 0.52 \\
\hline & 7.77 & 8.93 & 5.63 & 7.77 & 8.93 & 5.63 \\
\hline \multicolumn{4}{|c|}{ Median Stone Diameter for riprap at: left abutment } & right & abutment, & ft \\
\hline Fr<=0.8 (vertical abut.) & 2.09 & 3.11 & 0.96 & 2.09 & 3.11 & 0.96 \\
\hline Fr>0.8 (vertical abut.) & $\mathrm{ERR}$ & ERR & ERR & ERR & ERR & $\mathrm{ERR}$ \\
\hline
\end{tabular}

